\title{
Wind power characteristics of seven data collection sites in Jubail, Saudi Arabia using Weibull parameters
}

\author{
. A. Baseerab ${ }^{*}$, J.P. Meyera, S. Rehmanc, Md. M. Alamd. \\ aMechanical and Aeronautical Engineering Department, University of Pretoria, Pretoria, South \\ Africa \\ bDepartment of Mechanical \& Manufacturing Engineering Technology , Jubail Industrial \\ College, Jubail, Saudi Arabia \\ E-mail: abaseer77@yahoo.com \\ *Corresponding author \\ E-mail: Josua.Meyer@up.ac.za \\ cCenter for Engineering Research, Research Institute, King Fahd University of Petroleum and \\ Minerals, Dhahran-31261, Saudi Arabia \\ E-mail: srehman@kfupm.edu.sa \\ dInstitute for Turbulence-Noise-Vibration Interaction and Control, Shenzhen Graduate School, \\ arbin Institute of Technology, Shenzhen 518055, China \\ E-mail: alamm28@yahoo.com
}

\begin{abstract}
:
The wind characteristics of seven locations in Jubail, Saudi Arabia were analysed by using five years of wind data of six sites and three years data of one site at $10 \mathrm{~m}$ above ground level (AGL). The highest annual mean wind speed of $4.52 \mathrm{~m} / \mathrm{s}$ was observed at Industrial area (east) and lowest of $2.52 \mathrm{~m} / \mathrm{s}$ at Pearl beach with standard deviations of 2.52 and $1.1 \mathrm{~m} / \mathrm{s}$ respectively. Weibull parameters were estimated using maximum likelihood, least-squares regression method (LSRM) and WAsP algorithm. The most probable and maximum energy carrying wind speed were found by all the three methods. The correlation coefficient $\left(\mathrm{R}^{2}\right)$, root mean square error (RMSE), mean bias error $(\mathrm{MBE})$ and mean bias absolute error (MAE) showed that all three methods represent wind data at all sites accurately. However, the maximum likelihood method is slightly better than LSRM followed by WAsP algorithm. The wind power output at all seven sites from five commercially available wind machines of rated power from 1.8 - 3.3 MW showed that Jubail industrial area (east) is most promising. The energy output from a $3 \mathrm{MW}$ wind machine at this site was found to be 11,136 MWh/yr. with a plant capacity factor (PCF) of $41.3 \%$.
\end{abstract}


Keywords: Wind power; Weibull parameters; maximum energy carrying wind speed; most probable wind speed; plant capacity factor.

\section{Introduction}

The term green energy is used for those sources of energy which do not produce any of the harmful greenhouse gases. Further, the cleanest sources of energy are those which utilise the natural flows of the earth. These sources are known as renewable sources of energy and they will never die out unlike fixed reserves of fossil and nuclear fuels which emit greenhouse gases. Wind energy is one of the promising sources of renewable energy and is getting worldwide recognition due to its competitive cost of production compared with traditional means.

Wind speed frequency distribution is an important statistical tool in predicting the wind energy output at a particular location [1]. The Weibull distribution function is found to represent the variable nature of wind speed better than other distributions in most of the locations worldwide [2, 3, 4,5]. The Weibull function is a two-parameter function, namely, shape parameter, $\mathrm{k}$ and scale parameter, $\mathrm{c}$. There are several methods available in the literature for the determination of these two parameters. Stevens and Smulders [6] found the values of $k$ and $c$ by five different estimation methods namely, method of moments, method of energy pattern factor, maximum likelihood method, Weibull probability paper method and percentile estimators. Almost same values were obtained by all five methods.

Seguro and Lambert [7] calculated the Weibull parameters using maximum likelihood method, graphical method and modified maximum likelihood method. It was reported that when wind speed data is available in time-series format, the maximum likelihood method is the recommended method for estimating the parameters. When wind speed data is available in frequency distribution format, the modified maximum likelihood method is the recommended method. The graphical method is reported to be the least accurate. Bagiorgas et al. [8] calculated the Weibull parameters using the wind data 
from seven different sites in Saudi Arabia. The parameter estimation methods used were least-squares regression method, method of moments, alternative maximum likelihood estimation method, maximum likelihood method, and WAsP Algorithm. The calculated values using the five different methods were found to be in good agreement at all the measurement heights. The correlation between the monthly mean values of Weibull scale parameter and the measured wind speed values was found to be linear at all the sites.

Rocha et al. [9] compared seven numerical methods for determining the Weibull parameters at northeast region of Brazil. The estimation methods were graphical method, maximum likelihood method, energy pattern factor method, moment method, empirical method, modified maximum likelihood method, and equivalent energy method. The equivalent energy method was found to be efficient for determining the $\mathrm{k}$ and c parameters to fit Weibull distribution curves for wind speed data.

Akdag and Dinler [10] developed a new method called power density method for estimation of Weibull parameters. This new method was compared with graphic, maximum likelihood and moment methods and it was concluded that power density method is suitable and efficient for Weibull parameters estimation for the given location.

Wind speed assessment of six sites in the island of Crete, Greece was done [11]. The effect of topographical features on wind characteristics was studied. The Weibull, Rayleigh, Lognormal, Gamma, and Inverse Gaussian distributions probability distributions were examined for their ability to model the wind speed frequency distributions. The most efficient methods for the estimation of the distribution parameters were found to be moments method, maximum likelihood method, and least-squares method.

For wind resource assessment of Selcuk University campus in Turkey, one year wind data at three different heights was analysed [12]. Energy output from a 6 MW installed 
capacity wind farm composed of 1.0, 1.5, and 2.0 MW rated power wind turbines was calculated and reported by Faruk et al. [12]. The minimum basic payback period was found to be 6.44 years.

Onea et al. [13] presented the wind resource assessment of north-western side of the Black Sea using measured wind speed data over a period of 11 years. The analysis indicated that the Romanian coastal region has more wind energy potential during the winter season, with an average annual wind speed of about $9.7 \mathrm{~m} / \mathrm{s}$ at $80 \mathrm{~m}$ and a power density of $870 \mathrm{~W} / \mathrm{m}^{2}$. This study concluded that the north-western side of the Black Sea is a promising site for the wind farm development.

The forecast of energy demand in Saudi Arabia is expected to be more than double in the next one and a half decade, from 58 GW in 2015 to $121 \mathrm{GW}$ in 2030 [14]. It is an urgent requirement to fill this gap of approx. $60 \mathrm{GW}$ of power generation and at the same time reduce the load on diminishing oil and gas reserves. Wind energy along with solar energy - Photovoltaic (PV) and Concentrated Solar Power (CSP) are serious considerations to fill this energy gap [14]. This study aims at conducting a comprehensive and accurate wind resource assessment at seven locations of the largest industrial enterprise in middle-east by finding Weibull parameters, maximum energy carrying capacity, most probable wind speed, energy output from a few commercially available wind machines and comparing parameter estimation methods.

\section{Sites, equipment and data description}

In 1933, geologists explored oil in Jubail, Saudi Arabia. In 1983, the largest engineering and construction project ever was started at Jubail industrial city. Presently, Jubail industrial city is host to more than 160 industrial enterprises and home to almost 95,000 residents. The Jubail infrastructure has the capability to operate continuously without failure of power in any of the existing facilities while meeting community requirements 
within high modern living standards where all the necessities of life and tourism and recreation are available.

To study the viability of wind power generation for the Jubail city, the historical wind data from seven weather stations was obtained from the Environment and Control Department (Royal commission for Jubail). The locations of these sites are shown in Fig. 1. The photos of the wind towers at Industrial area (central), Al Bahar desalination plant, Pearl beach and Al-Reggah district are shown in Fig. 2, 3, 4 and 5 respectively. All the seven sites are located within a radius of $20 \mathrm{kms}$. The availability of long term wind speed data or an accurate forecasting method for missing data is very important in identifying suitable locations for wind turbines [15]. This governmental organisation is responsible for the maintenance, calibration and collection of meteorological data at Jubail Industrial city. The latitude/longitude and UTM coordinates of the weather station are given in Table. 1. The specifications of the wind speed sensors installed on the wind tower are given in Table 2. The list of weather parameters recorded is given in Table 3 . The description of the terrain in the vicinity of all the sites is given in Table 4 .

The coastal city of Jubail also hosts world's largest water desalination plant, Saline water conversion corporation, SWCC. This plant produces 363.4 million cubic meters of water per annum supplying it to national capital, Riyadh and Jubail [16]. The desalination in this plant is done by conventional means and out of all the alternatives of renewable energy desalination, wind powered desalination can be considered most promising [17]. 


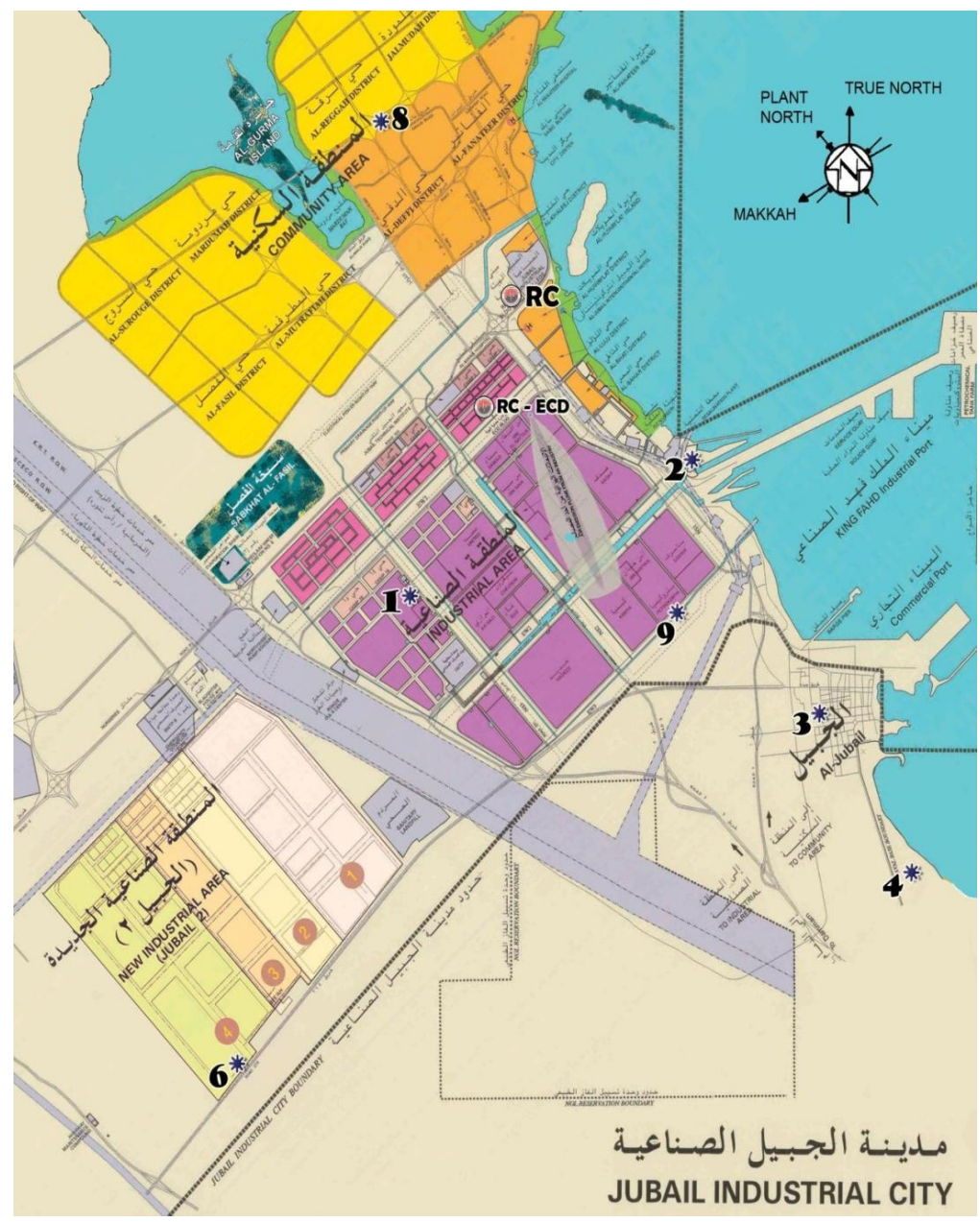

Fig. 1. Weather stations in Jubail industrial city

Table 1

Latitude/longitude and UTM coordinates of weather data collection sites.

\begin{tabular}{|c|c|c|c|}
\hline $\begin{array}{l}\text { Site } \\
\text { Code }\end{array}$ & Site name & $\begin{array}{l}\text { Degrees, } \\
\text { Minutes, } \\
\text { Secondss }\end{array}$ & $\begin{array}{l}\text { Station } \\
\text { height, m } \\
\text { AGL }\end{array}$ \\
\hline \multirow[t]{2}{*}{ Site 1} & \multirow{2}{*}{$\begin{array}{l}\text { Industrial area } \\
\text { (Central) }\end{array}$} & $27^{\circ} 2^{\prime} 15.76^{\prime \prime} \mathrm{N}$ & \multirow[t]{2}{*}{$10,50 \& 90$} \\
\hline & & $49^{\circ} 32^{\prime} 2.56^{\prime \prime} \mathrm{E}$ & \\
\hline \multirow[t]{2}{*}{ Site 2} & \multirow{2}{*}{$\begin{array}{l}\text { Al-Bahar } \\
\text { desalination plant }\end{array}$} & $27^{\circ} 4^{\prime} 27.49^{\prime \prime} \mathrm{N}$ & \multirow[t]{2}{*}{10} \\
\hline & & $49^{\circ} 36^{\prime} 3.24 " \mathrm{E}$ & \\
\hline \multirow[t]{2}{*}{ Site 3} & \multirow[t]{2}{*}{ Pearl beach } & $27^{\circ} 0{ }^{\prime} 36.85^{\prime \prime} \mathrm{N}$ & \multirow[t]{2}{*}{10} \\
\hline & & $49^{\circ} 39^{\prime} 9.56 " \mathrm{E}$ & \\
\hline \multirow[t]{2}{*}{ Site 4} & \multirow[t]{2}{*}{ Naval Base } & $26^{\circ} 55^{\prime} 39.92^{\prime \prime} \mathrm{N}$ & \multirow[t]{2}{*}{10} \\
\hline & & $49^{\circ} 42^{\prime} 42.89^{\prime \prime} \mathrm{E}$ & \\
\hline \multirow[t]{2}{*}{ Site 6} & \multirow{2}{*}{$\begin{array}{l}\text { Industrial area } 2 \\
\text { (South) }\end{array}$} & $26^{\circ} 55^{\prime} 13.40^{\prime \prime} \mathrm{N}$ & \multirow[t]{2}{*}{10} \\
\hline & & $49^{\circ} 29^{\prime} 0.10^{\prime \prime} \mathrm{E}$ & \\
\hline \multirow[t]{2}{*}{ Site 8} & \multirow[t]{2}{*}{ Al-Reggah District } & $27^{\circ} 7^{\prime} 54.03^{\prime \prime} \mathrm{N}$ & \multirow[t]{2}{*}{10} \\
\hline & & $49^{\circ} 31^{\prime} 57.02^{\prime \prime} \mathrm{E}$ & \\
\hline \multirow[t]{2}{*}{ Site 9} & \multirow[t]{2}{*}{ Industrial area (East) } & $27^{\circ} 1 ' 49.95^{\prime \prime} \mathrm{N}$ & \multirow[t]{2}{*}{10} \\
\hline & & $49^{\circ} 36^{\prime} 41.14^{\prime \prime} \mathrm{E}$ & \\
\hline
\end{tabular}


Table 2

Specifications of the wind speed sensor at data collection site.

\begin{tabular}{|l|l|}
\hline \multicolumn{1}{|l|}{ PERFORMANCE CHARACTERISTICS } \\
\hline Maximum Operating Range: & $0-125 \mathrm{mph}(0-60 \mathrm{~m} / \mathrm{s})$ \\
\hline Starting Speed: & $0.5 \mathrm{mph}(0.22 \mathrm{~m} / \mathrm{s})$ \\
\hline Calibrated Range: & $0-100 \mathrm{mph}(0-50 \mathrm{~m} / \mathrm{s})$ \\
\hline Accuracy: & $\pm 1 \%$ or $0.15 \mathrm{mph}(0.07 \mathrm{~m} / \mathrm{s})$ \\
\hline Resolution: & $<0.1 \mathrm{mph}$ or $\mathrm{m} / \mathrm{s}$ \\
\hline Temperature Range: & $-50^{\circ} \mathrm{C}$ to $+65^{\circ} \mathrm{C}\left(-58^{\circ} \mathrm{F}\right.$ to $\left.+149^{\circ} \mathrm{F}\right)$ \\
\hline Distance Constant: & less than $5 \mathrm{ft}(1.5 \mathrm{~m})$ of flow (meets EPA specifications) \\
\hline ELECTRICAL CHARACTERISTICS \\
\hline Power Requirements: & 12 VDC at $10 \mathrm{~mA}, 12$ VDC at $350 \mathrm{~mA}$ for internal heater \\
\hline Output Signal: & 11 volt (pulse frequency equivalent to speed) \\
\hline Output Impedance: & $100 \Omega$ maximum \\
\hline PHYSICAL CHARACTERISTICS \\
\hline Weight: & $1.5 \mathrm{lbs}(.68 \mathrm{~kg})$ \\
\hline Finish: & Clear anodised aluminium; Lexan cup assembly. \\
\hline CABLE \& MOUNTING & \\
\hline PN 1953 Mounting: & Cable Assembly; specify length in feet or metres PN 191 \\
\hline
\end{tabular}

Table 3

Parameter list of the weather data collection tower.

\begin{tabular}{|l|l|l|l|}
\hline Sr.No & Parameter Code & Description & Unit \\
\hline 1 & ATM & Atmospheric Temperature & DegC \\
\hline 2 & PRE & Precipitation & $\mathrm{mm}$ \\
\hline 4 & RH & Relative Humidity & $\%$ \\
\hline 6 & VWD10 & Vector Wind Direction $10 \mathrm{~m}$ & $\mathrm{deg}$ \\
\hline 9 & VWS10 & Vector Wind Speed 10m & $\mathrm{m} / \mathrm{s}$ \\
\hline
\end{tabular}

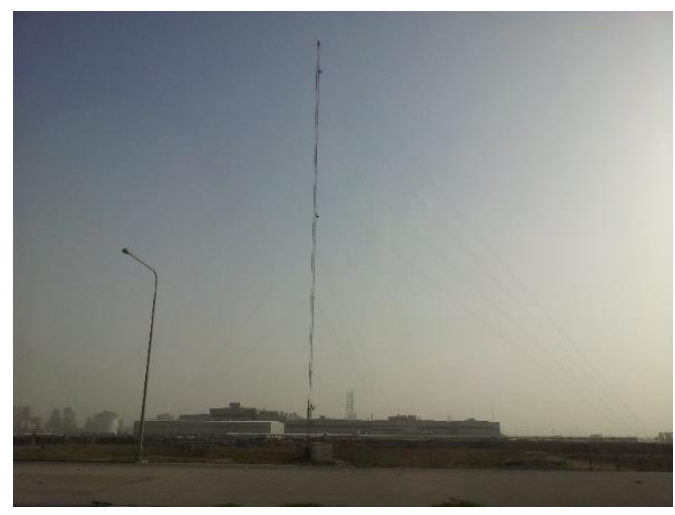

Fig. 2. Wind tower at Industrial area (Central)

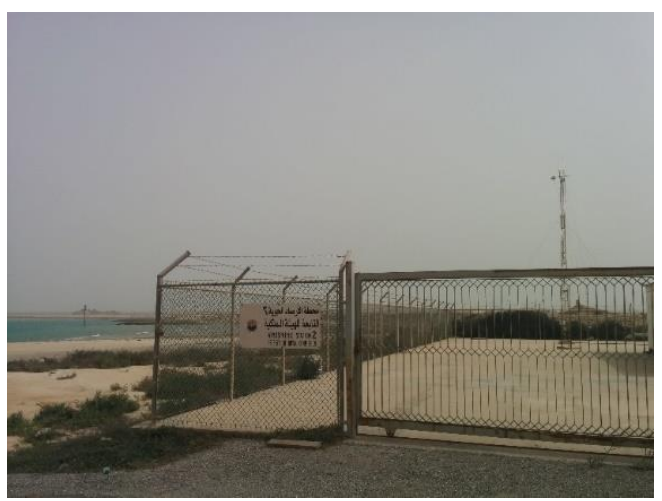

Fig. 3. Wind tower at Al-Bahar desalination plant 


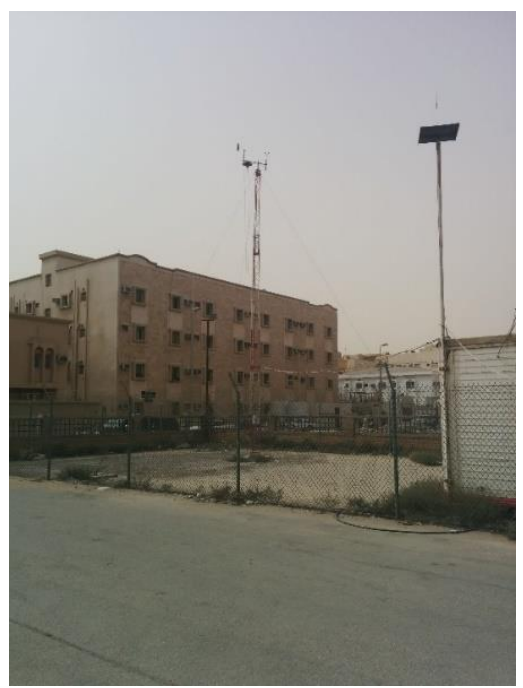

Fig. 4. Wind tower at Pearl beach

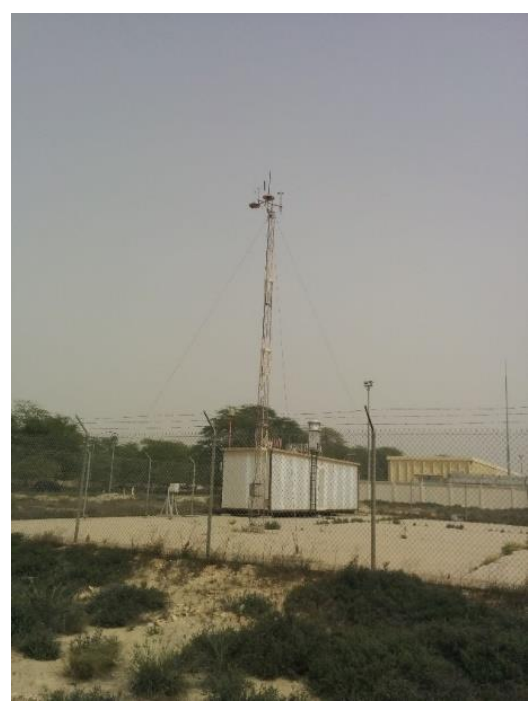

Fig. 5. Wind tower at Al-Reggah district

Table 4

Description of the terrain in the vicinity of weather stations.

\begin{tabular}{|l|l|}
\hline \multicolumn{1}{|c|}{ Site } & \multicolumn{1}{c|}{ Description } \\
\hline $\begin{array}{l}\text { Industrial area } \\
\text { (Central) }\end{array}$ & $\begin{array}{l}\text { Only station where weather data is available at three heights AGL. Surrounded } \\
\text { mainly by plain terrain with some warehouses of } 8-10 \mathrm{~m} \text { height about } 200 \mathrm{~m} \\
\text { away in west direction. }\end{array}$ \\
\hline $\begin{array}{l}\text { Al-Bahar } \\
\text { desalination plant }\end{array}$ & $\begin{array}{l}\text { Located on sea shore near desalination plant. Terrain is mostly plain and } \\
\text { surrounded by very small shrubs. }\end{array}$ \\
\hline Pearl beach & $\begin{array}{l}\text { Located in Jubail residential area and surrounded by 3-4 story buildings. This } \\
\text { station recorded minimum wind speed out of all weather stations. }\end{array}$ \\
\hline Naval Base & $\begin{array}{l}\text { Located near Dhahran-Jubail highway. Terrain is mostly plain and surrounded } \\
\text { by very small shrubs and few residential buildings 200 m away towards east. }\end{array}$ \\
\hline $\begin{array}{l}\text { Industrial area 2 } \\
\text { (South) }\end{array}$ & $\begin{array}{l}\text { Surrounded mainly by plain terrain with some warehouses of } 8-10 \mathrm{~m} \text { height } \\
\text { about 300 m away in west and north direction. }\end{array}$ \\
\hline $\begin{array}{l}\text { Al-Reggah } \\
\text { District }\end{array}$ & $\begin{array}{l}\text { Location mostly surrounded by shrubs. Surrounding clear with a 3 story } \\
\text { building around 150 m away in north-eastern direction. }\end{array}$ \\
\hline $\begin{array}{l}\text { Industrial area } \\
\text { (East) }\end{array}$ & $\begin{array}{l}\text { Surrounded mainly by plain terrain with some warehouses of } 8-10 \mathrm{~m} \text { height } \\
\text { about 150 m away in north - west direction }\end{array}$ \\
\hline
\end{tabular}

3. This study presents the analysis of wind characteristics from seven different sites at Jubail city in Saudi Arabia at $10 \mathrm{~m}$ height above ground level (AGL). The wind data is collected over a period of 5 years $(2008$ - 2012) for all sites except the site at Naval base where the data was available for 3 years $(2010$ - 2012).

\subsection{Statistics of Wind Speed}

The hourly average wind speed values over entire period of data collection for all the seven sites at $10 \mathrm{~m}$ height are presented in Table 5 . The highest annual mean wind 
speed of $4.53 \mathrm{~m} / \mathrm{s}$ was observed at Industrial area (East) and the lowest of $2.25 \mathrm{~m} / \mathrm{s}$ at Pearl beach with standard deviations of 2.52 and $1.1 \mathrm{~m} / \mathrm{s}$ respectively. To assess the seasonal variation of wind speed over all sites, the data is sorted month-wise and the monthly maximum, daily high/low (in that month), mean, and monthly minimum wind speeds are plotted. These plots are shown in Fig. 6. It was observed that the highest monthly mean wind speed was witnessed in February/June at all sites; this period coincides with the high energy demand period for the region due to air conditioning load. The lowest mean wind speed was witnessed in September/October at all sites. To visualize the wind patterns at all the sites, the wind rose charts, showing the frequency and speed of wind blowing from each of 16 cardinal directions were plotted as shown in Fig. 7. These rose plots for a particular site can help in wind machine design decisions. It can be observed from these plots that the most prevailing wind direction at all sites was from the north-west.

Table 5

Wind speed statistics of all sites.

\begin{tabular}{|l|r|r|r|}
\hline \multirow{2}{*}{ Station } & \multicolumn{3}{|c|}{ Annual mean wind speed, m/s } \\
\cline { 2 - 4 } & Mean & Maximum & $\begin{array}{l}\text { Standard } \\
\text { Deviation }\end{array}$ \\
\hline Industrial area (Central) & 3.27 & 11.90 & 1.985 \\
\hline Al-Bahar desalination plant & 3.74 & 2.40 & 2.193 \\
\hline Pearl beach & 2.26 & 8.70 & 1.109 \\
\hline Naval Base & 3.78 & 13.80 & 2.220 \\
\hline Industrial area 2 (South) & 4.31 & 27.00 & 2.983 \\
\hline Al-Reggah District & 2.91 & 13.60 & 1.511 \\
\hline Industrial area (East) & 4.53 & 19.30 & 2.520 \\
\hline
\end{tabular}




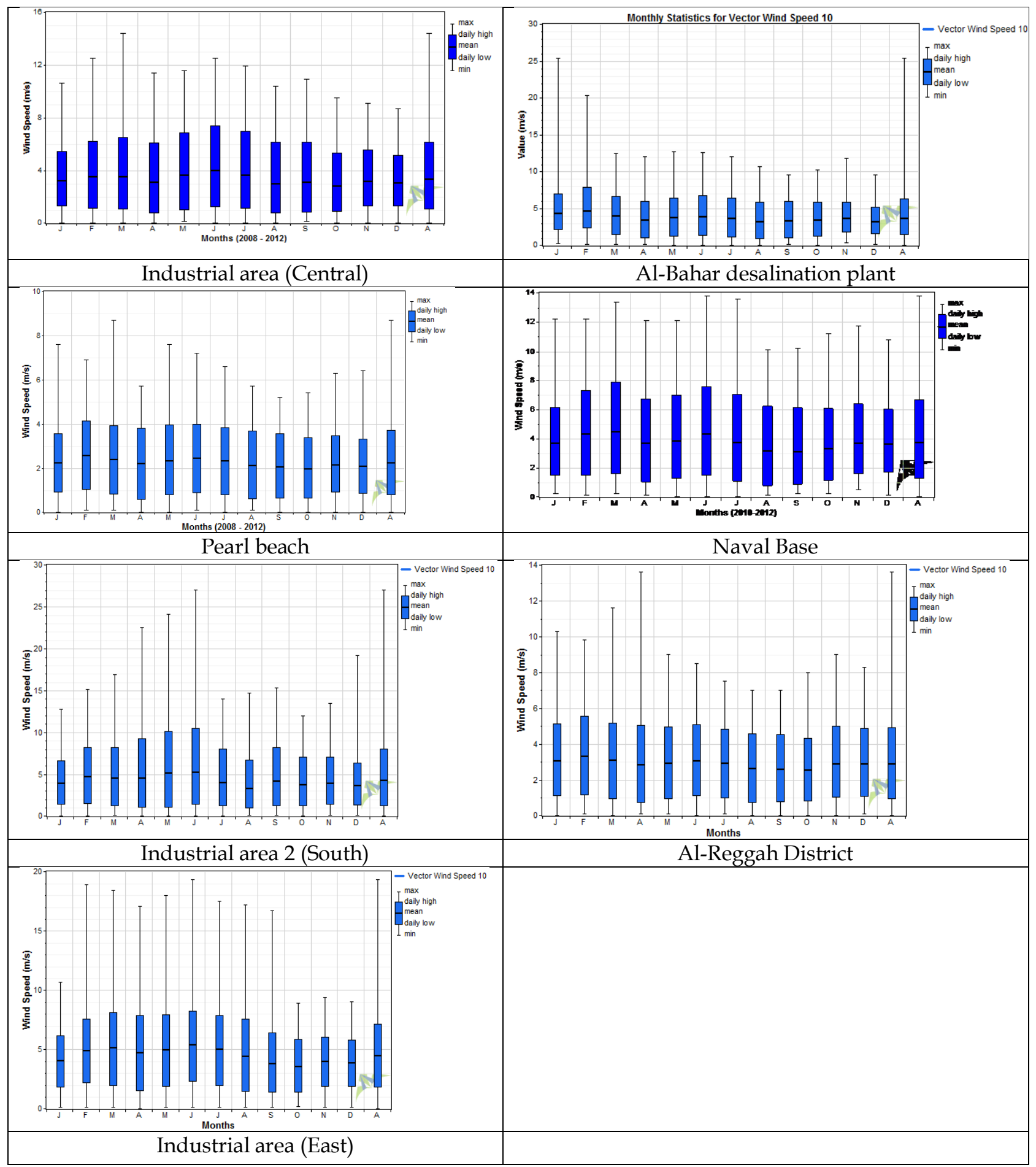

Fig. 6. Monthly maximum, daily high, daily mean, daily low and minimun wind speed at all sites. 


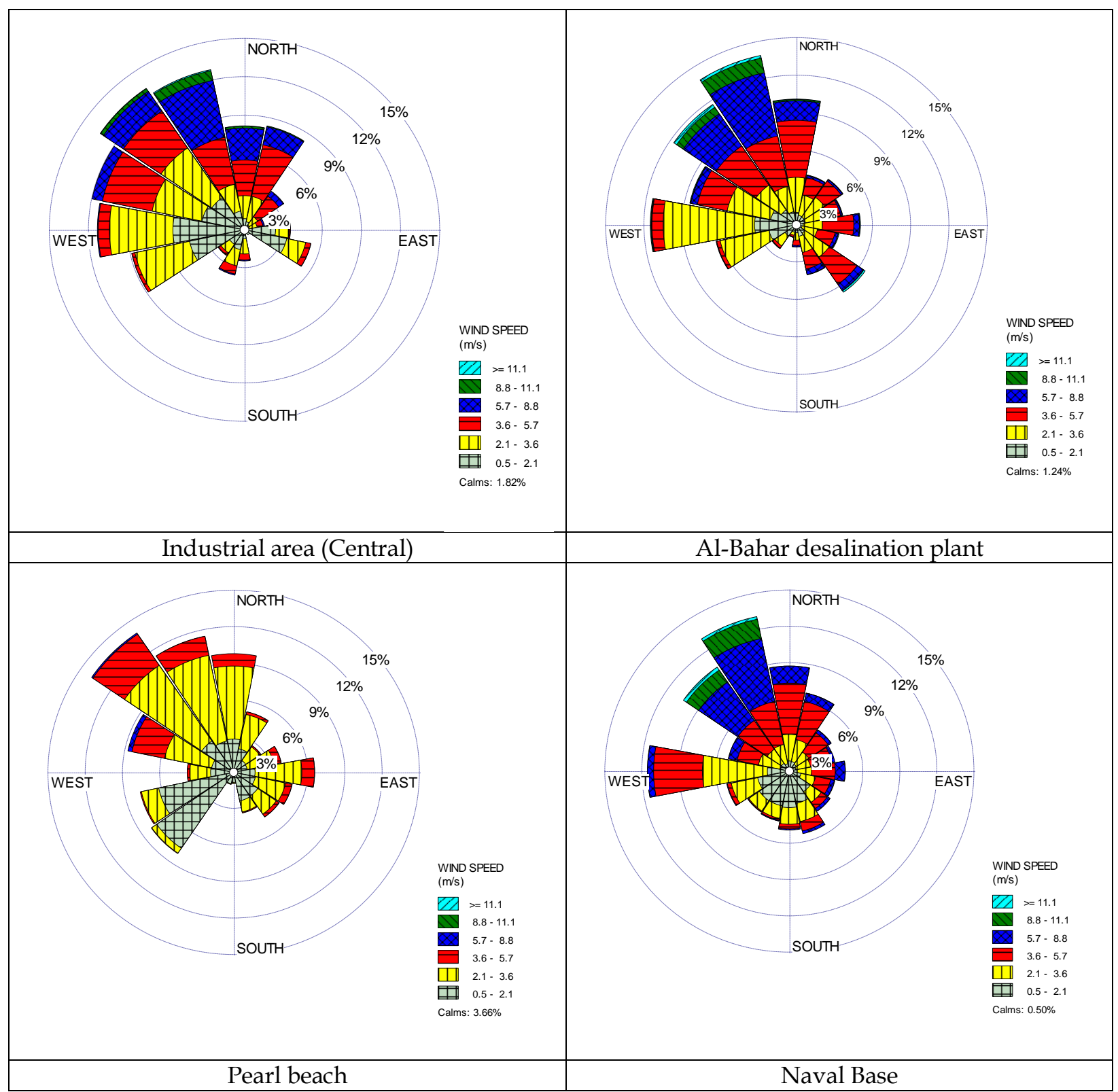




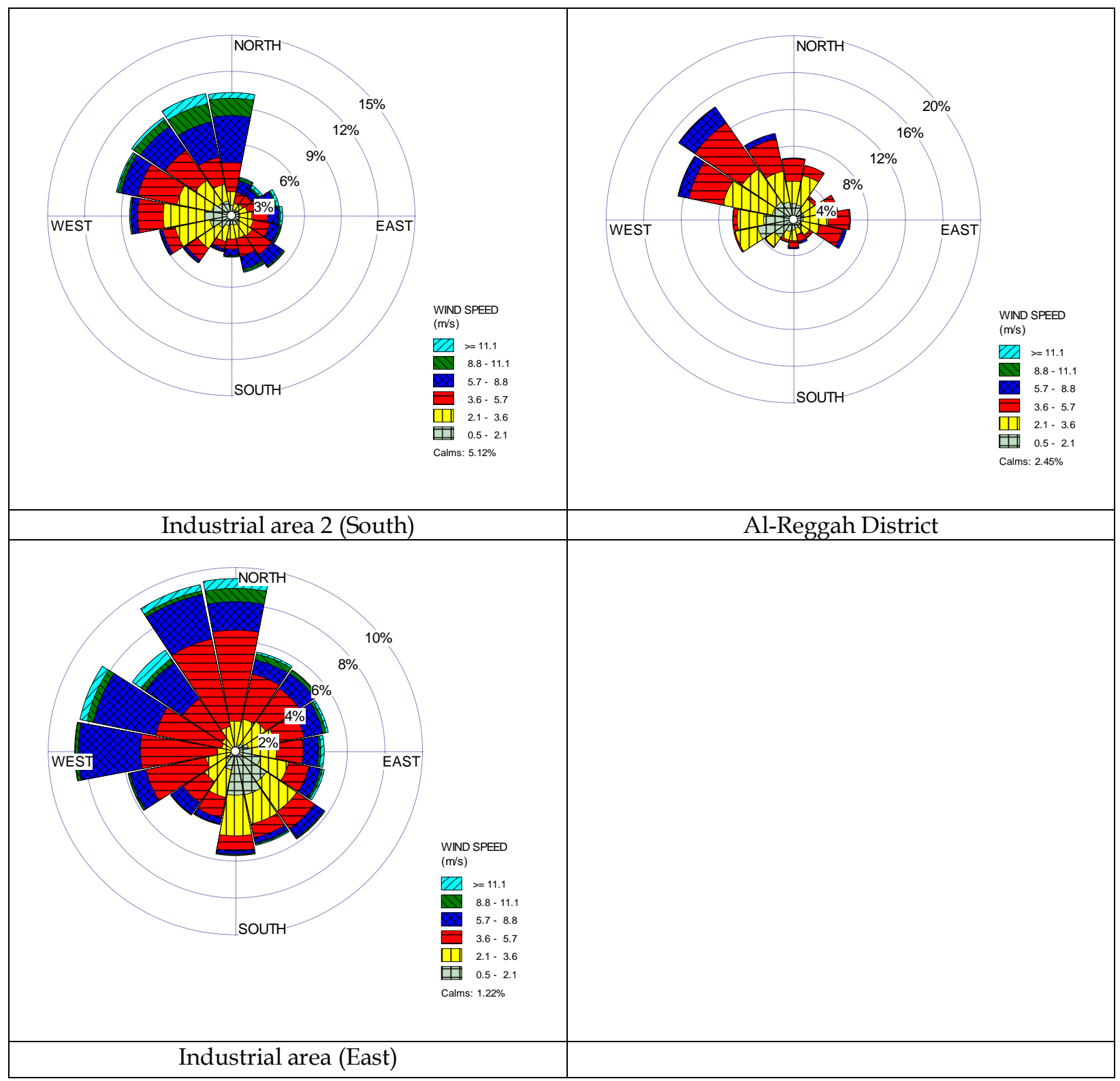

Fig. 7. Wind rose plots at $10 \mathrm{~m}$ AGL at all sites

\section{Numerical methods for determining the Weibull parameters}

The two-parameter Weibull distribution is frequently used to characterise wind behaviour because it provides a good representation of wind data [2, 3, 4, 5]. This distribution function shows the probability of the wind speed in a $1 \mathrm{~m} / \mathrm{s}$ bins centered on a particular wind data time series. The Weibull distribution function is expressed as [18]: 


$$
P_{(v)}=\frac{k}{v}\left(\frac{v}{c}\right)^{k-1} \exp \left\{-\left(\frac{v}{c}\right)^{k}\right\}
$$

Where $P_{(v)}$ is the frequency of incidence of wind speed, $v$. The scale factor, $c$ in $\mathrm{m} / \mathrm{s}$, is indicative of mean wind speed and $k$ is the dimensionless shape factor, which describes the shape and width of the distribution. The Weibull distribution is therefore determined by the parameters, $c$ and $k$. The cumulative Weibull distribution, $P_{(v) \text {, which }}$ gives the probability of the wind speed greater than the value, $v$, is expressed as:

$$
P(v)=\exp \left\{-\left(\frac{v}{c}\right)^{k}\right\}
$$

There are several methods to estimate Weibull parameters. Three methods commonly used are discussed in this study.

\subsection{Maximum Likelihood Method}

Maximum likelihood method was suggested by Stevens and Smulders [6]. This method requires extensive iterative calculations. Shape and scale parameters of Weibull distribution are estimated by these two equations

$$
\begin{aligned}
& k=\left(\frac{\sum_{i=1}^{n} v_{i}^{k} \ln \left(v_{i}\right)}{\sum_{i=1}^{n} v_{i}^{k}}-\frac{\sum_{i=1}^{n} \ln \left(v_{i}\right)}{n}\right)^{-1} \\
& c=\left(\frac{\sum_{i=1}^{n}\left(v_{i}\right)^{k}}{n}\right)^{\frac{1}{k}}
\end{aligned}
$$

Where $v_{i}$ is the wind speed and $\mathrm{n}$ is the number of nonzero wind speeds. This method is implemented by taking care of zero wind speeds which make logarithm indefinite and then calculate shape parameter. The scale parameter is found using a numerical technique in order to find the root of Eq. (3) around $k=2$.

\subsection{Least-Squares Regression Method (LSRM)}

The equation of the probability density function, after a double logarithmic transformation, can be written as follows:

$$
\ln [-\ln (1-F(v))]=k \ln (c)
$$


The above equation is linear and can be fitted using the LSRM [19]. The cumulative distribution function $F(v)$ can be estimated easily, using an estimator, which is the median rank.

The wind power density, WPD, for maximum likelihood method and least-squares regression method is computed using the following equation:

$$
W P D=\frac{1}{2} \rho c^{3}
$$

Where:

$\rho$ : air density within the time step, $\mathrm{kg} / \mathrm{m}^{3}$.

$c$ : weibull scale parameter, measure of average wind speed within the time step, $\mathrm{m} / \mathrm{s}$.

\subsection{WAsP Algorithm}

There are two requirements of WAsP algorithm

(1) The power density of the fitted Weibull distribution is equal to that of the observed distribution and

(2) The proportion of values above the mean is the same for the fitted Weibull distribution as for the observed distribution.

Let $X$ represents the proportion of the observed wind speeds that exceed the mean wind speed. The cumulative distribution function $F(U)$ gives the proportion of values that are less than $U$, so $1-F(U)$ is the proportion of values that exceed $U$. One can therefore write the second requirement as follows:

$$
X=1-F(\bar{U})
$$

Since the mean wind speed is given by the following equation:

$$
\bar{U}=c \Gamma\left(\frac{1}{k}+1\right)
$$

Substitute the aforementioned mean value in the expression of the cumulative distribution function to get second requirement:

$$
X=\exp \left[-\Gamma\left(\frac{1}{k}+1\right)^{k}\right]
$$


Taking the natural logarithm of both sides gives

$$
-\ln X=\Gamma\left(\frac{1}{k}+1\right)^{k}
$$

In performing the WAsP algorithm to fit the Weibull distribution, WindoGrapher [20] software (http://www.mistaya.ca/) calculates $X$ and then solves the above equation iteratively by using the Brent method, in order to find the k parameter. Requirement (1) allows us to calculate the c parameter. On the basis of the Weibull distribution, in WAsP algorithm, the mean WPD, assuming constant air density, is calculated as follows:

$$
W P D=\frac{1}{2} \rho c^{3} \Gamma\left(\frac{3}{k}+1\right)
$$

We can also write an equation for the mean power density of the observed wind speeds as follows:

$$
W P D=\frac{1}{2 N} \rho \sum_{N} U_{i}^{3}
$$

As per requirement (1), these must be equal, so one can write,

$$
c^{3} \Gamma\left(\frac{3}{k}+1\right)=\frac{1}{N} \sum_{N} U_{i}^{3}
$$

Solving this for $c$ gives us the following:

$$
c=\sqrt[3]{\frac{\sum_{N} U_{i}^{3}}{N \Gamma\left(\frac{3}{k}+1\right)}}
$$

The actual wind data and Weibull curves at all seven sites (maximum likelihood method, lease squares regression methods and WAsP method) are also shown in Fig. 8. 


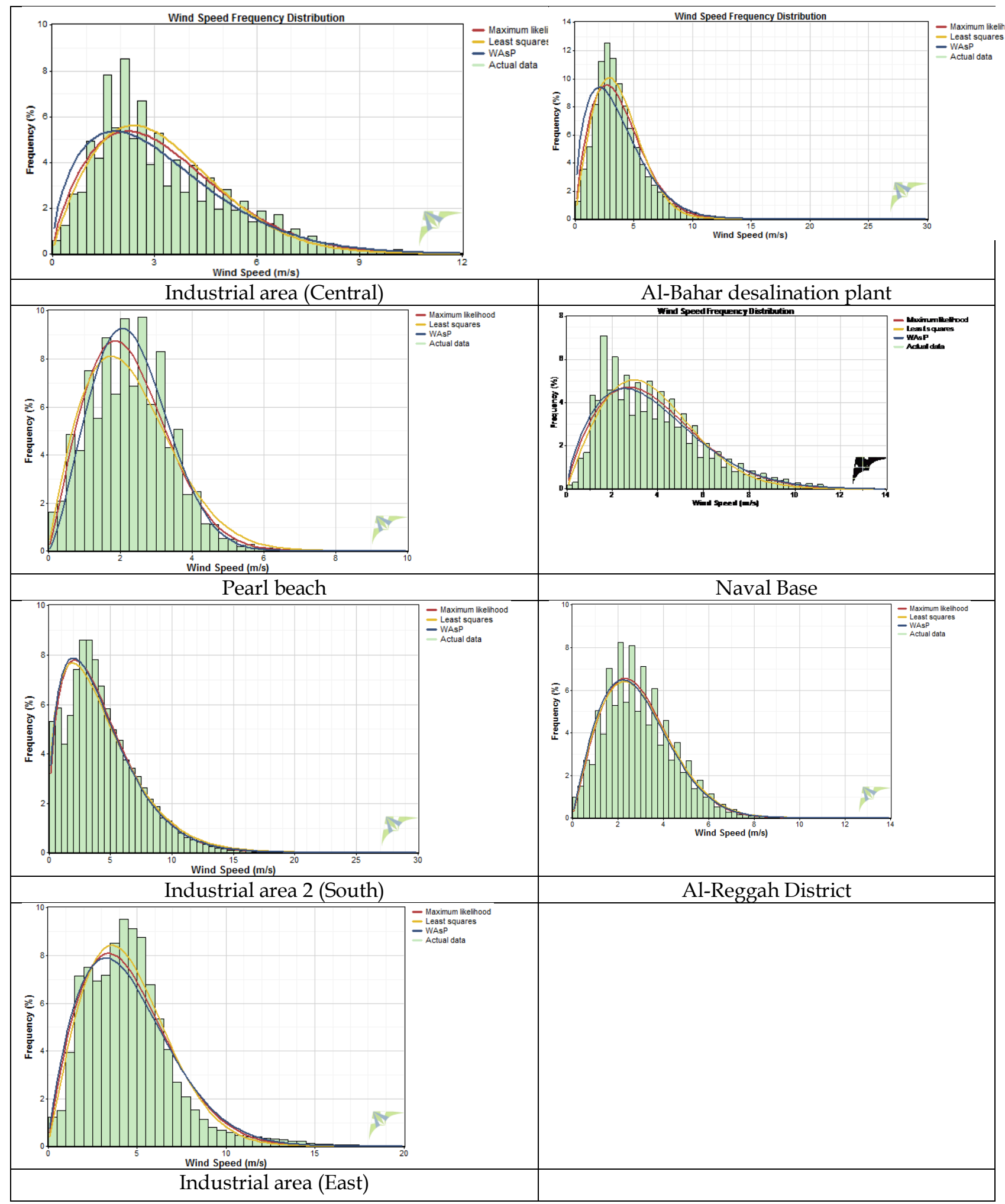

Fig. 8. Weibull probability distributions (three methods) and actual data at all sites. 


\section{Goodness-of-fit tests}

To analyse the efficiency of the aforementioned Weibull parameter estimation methods, the following tests were conducted:

Coefficient of determination, $R^{2}$, is the square of correlation between the frequency of Weibull to that of actual observations.

The coefficient of determination is computed according to the following equation [21, 9]:

$$
R^{2}=\frac{\sum_{i=1}^{N}\left(y_{i}-z_{i}\right)^{2}-\sum_{i=1}^{N}\left(y_{i}-x_{i}\right)^{2}}{\sum_{i=1}^{N}\left(y_{i}-z_{i}\right)^{2}-}
$$

The root mean square error, RMSE is the measure of the residuals of frequency of Weibull and actual observations [20].

$$
R M S E=\sqrt{\left[\frac{1}{N} \sum_{i=1}^{N}\left(y_{i}-x_{i}\right)^{2}\right]}
$$

The mean bias error, $M B E$ and mean bias absolute error, $M A E$ are a measure of how closely frequency of Weibull match the actual observations [21, 9].

$$
\begin{aligned}
& M B E=\frac{1}{N} \sum_{i=1}^{N}\left(y_{i}-x_{i}\right) \\
& M A E=\frac{1}{N} \sum_{i=1}^{N}\left|y_{i}-x_{i}\right|
\end{aligned}
$$

Where:

$N$ is the number is observations, $y_{i}$ is the frequency of observation, $x_{i}$ is the frequency of Weibull and $z_{i}$ is the mean wind speed

\section{Results and discussion}

The Weibull scale and shape parameters ( $c$ and $k)$, wind power density (WPD) and statistical results $\left(R^{2}, R S M E, M B E\right.$ and $\left.M A E\right)$ for all sites estimated by Maximum likelihood method, least square regression method and WAsP method are shown in Tables 6 - 12. The average error in calculating the WPD was found to be $0.25 \%$ for maximum likelihood method, $6.8 \%$ for LSRM and $5.7 \%$ for WAsP method. It can be clearly validated by goodness-of-fit test indicators, i.e., $R^{2}, R S M E, M B E$ and $M A E$ at all sites that maximum likelihood method is the best method to represent the wind regime 
in Jubail, very closely followed by least square regression and WAsP method. The monthly and annual Weibull parameters obtained by the most accurate method, maximum likelihood method are given in Table 13 and 14 respectively. The monthly and annual variation of Weibull parameters $\mathrm{k}$ and $\mathrm{c}$ is shown in Figs. 9, 10, 11 and 12.

Table 6

Weibull parameters, WPD and statistical results for Industrial area (Central).

\begin{tabular}{|c|c|c|c|c|c|c|c|}
\hline Parameter estimation method & $k$ & $\begin{array}{r}c \\
(\mathrm{~m} / \mathrm{s})\end{array}$ & $\begin{array}{r}\text { WPD } \\
\left(w / m^{2}\right)\end{array}$ & $R^{2}$ & $R M S E$ & $M B E$ & $M A E$ \\
\hline Maximum likelihood method & 1.724 & 3.675 & 48.5 & 0.86 & 0.175 & -0.0046 & 0.3132 \\
\hline $\begin{array}{l}\text { Least-Squares Regression } \\
\text { Method }\end{array}$ & 1.845 & 3.64 & 43.1 & 0.85 & 0.18112 & -0.0047 & 0.3228 \\
\hline WAsP method & 1.563 & 3.519 & 49.6 & 0.85 & 0.1849 & -0.0048 & 0.3547 \\
\hline
\end{tabular}

Table 7

Weibull parameters, WPD and statistical results for Al-Bahar desalination plant.

\begin{tabular}{|c|c|c|c|c|c|c|c|}
\hline Parameter estimation method & $k$ & $\begin{array}{r}c \\
(\mathrm{~m} / \mathrm{s})\end{array}$ & $\begin{array}{r}\text { WPD } \\
\left(\mathrm{w} / \mathrm{m}^{2}\right)\end{array}$ & $R^{2}$ & RMSE & $M B E$ & $M A E$ \\
\hline Maximum likelihood method & 1.8 & 4.218 & 69.2 & 0.96 & 0.072 & -0.0042 & 0.1758 \\
\hline $\begin{array}{l}\text { Least-Squares Regression } \\
\text { Method }\end{array}$ & 1.952 & 4.2 & 61.9 & 0.96 & 0.07257 & -0.0045 & 0.1784 \\
\hline WAsP method & 1.548 & 4.012 & 74.8 & 0.91 & 0.1449 & -0.003 & 0.2274 \\
\hline
\end{tabular}

Table 8

Weibull parameters, WPD and statistical results for Pearl beach.

\begin{tabular}{lccccccc}
\hline \multicolumn{1}{c}{ Parameter estimation method } & $\boldsymbol{k}$ & $\begin{array}{r}\boldsymbol{c} \\
(\mathbf{m} / \mathbf{s})\end{array}$ & $\begin{array}{c}\text { WPD } \\
\left(\mathbf{w} / \mathbf{m}^{2}\right)\end{array}$ & $\boldsymbol{R}^{2}$ & RMSE & MBE & MAE \\
\hline $\begin{array}{l}\text { Maximum likelihood method } \\
\text { Least-Squares Regression }\end{array}$ & 2.104 & 2.539 & 12.7 & 0.91 & 0.018 & -0.0047 & 0.1155 \\
$\begin{array}{l}\text { Method } \\
\text { WAsP method }\end{array}$ & 1.924 & 2.582 & 14.6 & 0.9 & 0.02308 & -0.0048 & 0.1433 \\
& 2.367 & 2.611 & 12.5 & 0.9 & 0.0235 & -0.005 & 0.1208 \\
\hline
\end{tabular}

Table 9

Weibull parameters, WPD and statistical results for Naval Base.

\begin{tabular}{lrrrrrrr}
\hline Parameter estimation method & $\boldsymbol{k}$ & $\begin{array}{r}\boldsymbol{c} \\
(\mathbf{m} / \mathbf{s})\end{array}$ & $\begin{array}{r}\text { WPD } \\
\left(\mathbf{w} / \mathbf{m}^{2}\right)\end{array}$ & $\boldsymbol{R}^{2}$ & $R M S E$ & MBE & MAE \\
\hline Maximum likelihood method & 1.799 & 4.263 & 71.4 & 0.86 & 0.16 & -0.005 & 0.3521 \\
$\begin{array}{l}\text { Least-Squares Regression } \\
\text { Method }\end{array}$ & 1.973 & 4.205 & 61.4 & 0.85 & 0.17172 & -0.0049 & 0.3619 \\
WAsP method & 1.718 & 4.218 & 73.7 & 0.84 & 0.1574 & -0.005 & 0.3522 \\
\hline
\end{tabular}


Table 10

Weibull parameters, WPD and statistical results for Industrial area 2 (South).

\begin{tabular}{lccccccc}
\hline Parameter estimation method & $\boldsymbol{k}$ & $\begin{array}{r}\boldsymbol{c} \\
(\mathrm{m} / \mathbf{s})\end{array}$ & $\begin{array}{c}\text { WPD } \\
\left(\mathbf{w} / \mathbf{m}^{2}\right)\end{array}$ & $\boldsymbol{R}^{2}$ & $\mathbf{R M S E}$ & MBE & MAE \\
\hline $\begin{array}{l}\text { Maximum likelihood method } \\
\text { Least-Squares Regression }\end{array}$ & 1.45 & 4.74 & 139.2 & 0.92 & 0.097 & -0.0034 & 0.1482 \\
$\begin{array}{l}\text { Method } \\
\text { WAsP method }\end{array}$ & 1.392 & 4.788 & 155.9 & 0.92 & 0.0958 & -0.0032 & 0.1624 \\
& 1.421 & 4.678 & 139.4 & 0.92 & 0.097 & -0.003 & 0.1491 \\
\hline
\end{tabular}

Table 11

Weibull parameters, WPD and statistical results for Al-Reggah District

\begin{tabular}{lccccccc}
\hline Parameter estimation method & $\boldsymbol{k}$ & $\begin{array}{r}\boldsymbol{c} \\
(\mathbf{m} / \mathbf{s})\end{array}$ & $\begin{array}{r}\text { WPD } \\
\left(\mathbf{w} / \mathbf{m}^{2}\right)\end{array}$ & $\boldsymbol{R}^{2}$ & RMSE & MBE & MAE \\
\hline Maximum likelihood method & 2.008 & 3.286 & 28.8 & 0.94 & 0.177 & -0.0048 & 0.3504 \\
$\begin{array}{l}\text { Least-Squares Regression } \\
\text { Method }\end{array}$ & 1.957 & 3.304 & 30.1 & 0.93 & 0.1782 & -0.0048 & 0.3497 \\
WAsP method & 1.938 & 3.242 & 28.7 & 0.93 & 0.178 & -0.005 & 0.3485 \\
\hline
\end{tabular}

Table 12

Weibull parameters, WPD and statistical results for Industrial area (East)

\begin{tabular}{lcrrrrrr}
\hline \multicolumn{1}{c}{ Parameter estimation method } & $\boldsymbol{k}$ & $\begin{array}{r}\boldsymbol{c} \\
(\mathbf{m} / \mathbf{s})\end{array}$ & $\begin{array}{c}\text { WPD } \\
\left(\mathbf{w} / \mathbf{m}^{2}\right)\end{array}$ & $\boldsymbol{R}^{2}$ & RMSE & MBE & MAE \\
\hline $\begin{array}{l}\text { Maximum likelihood method } \\
\text { Least-Squares Regression }\end{array}$ & 1.876 & 5.098 & 116 & 0.94 & 0.07 & -0.0048 & 0.2339 \\
$\begin{array}{l}\text { Method } \\
\text { WAsP method }\end{array}$ & 1.999 & 5.096 & 107.8 & 0.94 & 0.0705 & -0.0048 & 0.2139 \\
\hline
\end{tabular}

Table 13

Monthly Weibull parameters at all sites (Maximum likelihood method)

\begin{tabular}{|c|c|c|c|c|c|c|c|c|c|c|c|c|c|c|}
\hline \multirow{2}{*}{$\begin{array}{l}\text { Location } \\
\text { Month }\end{array}$} & \multicolumn{2}{|c|}{$\begin{array}{c}\text { Industrial area } \\
\text { (Central) }\end{array}$} & \multicolumn{2}{|c|}{$\begin{array}{c}\text { Al-Bahar } \\
\text { desalination } \\
\text { plant }\end{array}$} & \multicolumn{2}{|c|}{ Pearl beach } & \multicolumn{2}{|c|}{ Naval Base } & \multicolumn{2}{|c|}{$\begin{array}{c}\text { Industrial area } 2 \\
\text { (South) }\end{array}$} & \multicolumn{2}{|c|}{$\begin{array}{l}\text { Al-Reggah } \\
\text { District }\end{array}$} & \multicolumn{2}{|c|}{$\begin{array}{c}\text { Industrial area } \\
\text { (East) }\end{array}$} \\
\hline & $k$ & $c$ & $k$ & $c$ & $k$ & $c$ & $k$ & $c$ & $k$ & $c$ & $k$ & $c$ & $k$ & $c$ \\
\hline Jan & 1.892 & 3.691 & 1.572 & 4.869 & 2.016 & 2.539 & 2.013 & 4.202 & 1.666 & 4.443 & 1.845 & 3.467 & 2.415 & 4.591 \\
\hline Feb & 1.680 & 3.962 & 1.697 & 5.254 & 2.126 & 2.913 & 1.88 & 4.913 & 1.556 & 5.247 & 1.893 & 3.760 & 1.942 & 5.579 \\
\hline Mar & 1.700 & 4.003 & 1.835 & 4.556 & 2.108 & 2.698 & 1.73 & 5.053 & 1.566 & 5.058 & 1.942 & 3.483 & 1.91 & 5.817 \\
\hline Apr & 1.649 & 3.504 & 1.871 & 3.938 & 2.118 & 2.509 & 1.896 & 4.203 & 1.528 & 5.117 & 2.045 & 3.246 & 1.938 & 5.363 \\
\hline May & 1.662 & 4.106 & 1.759 & 4.247 & 2.253 & 2.644 & 1.825 & 4.409 & 1.382 & 5.662 & 2.178 & 3.314 & 1.909 & 5.644 \\
\hline Jun & 1.673 & 4.476 & 1.731 & 4.442 & 2.047 & 2.785 & 1.704 & 4.876 & 1.351 & 5.800 & 2.063 & 3.484 & 1.721 & 6.133 \\
\hline Jul & 1.675 & 4.133 & 1.885 & 4.159 & 2.307 & 2.651 & 1.692 & 4.279 & 1.266 & 4.378 & 2.259 & 3.313 & 1.940 & 5.706 \\
\hline Aug & 1.608 & 3.392 & 2.035 & 3.724 & 2.267 & 2.406 & 1.787 & 3.556 & 1.356 & 3.686 & 2.229 & 2.966 & 1.938 & 5.060 \\
\hline Sep & 1.762 & 3.533 & 2.033 & 3.802 & 2.256 & 2.343 & 1.888 & 3.543 & 1.643 & 4.753 & 2.165 & 2.95 & 1.473 & 4.244 \\
\hline Oct & 1.759 & 3.189 & 2.044 & 3.941 & 2.118 & 2.229 & 1.821 & 3.755 & 1.697 & 4.237 & 2.127 & 2.883 & 2.410 & 4.095 \\
\hline Nov & 2.056 & 3.639 & 2.169 & 4.180 & 2.258 & 2.436 & 2.101 & 4.237 & 1.625 & 4.436 & 2.024 & 3.290 & 2.699 & 4.516 \\
\hline Dec & 2.020 & 3.492 & 2.231 & 3.643 & 1.989 & 2.355 & 2.009 & 4.191 & 1.461 & 4.101 & 1.912 & 3.282 & 2.535 & 4.380 \\
\hline
\end{tabular}


Table 14

Annual Weibull parameters at all sites (Maximum likelihood method)

\begin{tabular}{|c|c|c|c|c|c|c|c|c|c|c|c|c|c|c|}
\hline \multirow[t]{2}{*}{ Year } & \multicolumn{2}{|c|}{$\begin{array}{c}\text { Industrial area } \\
\text { (Central) }\end{array}$} & \multicolumn{2}{|c|}{$\begin{array}{c}\text { Al-Bahar } \\
\text { desalination } \\
\text { plant }\end{array}$} & \multicolumn{2}{|c|}{ Pearl beach } & \multicolumn{2}{|c|}{ Naval Base } & \multicolumn{2}{|c|}{$\begin{array}{c}\text { Industrial area } 2 \\
\text { (South) }\end{array}$} & \multicolumn{2}{|c|}{$\begin{array}{l}\text { Al-Reggah } \\
\text { District }\end{array}$} & \multicolumn{2}{|c|}{$\begin{array}{c}\text { Industrial area } \\
\text { (East) }\end{array}$} \\
\hline & $k$ & $c$ & $k$ & $c$ & $k$ & $c$ & $k$ & $c$ & $k$ & $c$ & $k$ & $c$ & $k$ & $c$ \\
\hline 2008 & 1.714 & 3.971 & 1.603 & 4.777 & 2.128 & 2.667 & - & - & 1.989 & 5.480 & 1.941 & 3.363 & 2.434 & 4.757 \\
\hline 2009 & 1.700 & 3.658 & 1.899 & 4.301 & 2.109 & 2.548 & - & - & 1.875 & 5.251 & 1.992 & 3.318 & 2.318 & 4.450 \\
\hline 2010 & 1.701 & 3.611 & 1.913 & 4.163 & 2.111 & 2.443 & 1.811 & 4.151 & 1.660 & 4.338 & 1.996 & 3.141 & 2.457 & 4.671 \\
\hline 2011 & 1.743 & 3.880 & 1.927 & 3.641 & 2.178 & 2.578 & 1.834 & 4.429 & 1.194 & 3.849 & 2.104 & 3.343 & 2.320 & 4.563 \\
\hline 2012 & 1.724 & 3.675 & 1.987 & 4.229 & 2.057 & 2.467 & 1.763 & 4.212 & 1.096 & 4.685 & 2.025 & 3.261 & 1.876 & 5.098 \\
\hline
\end{tabular}

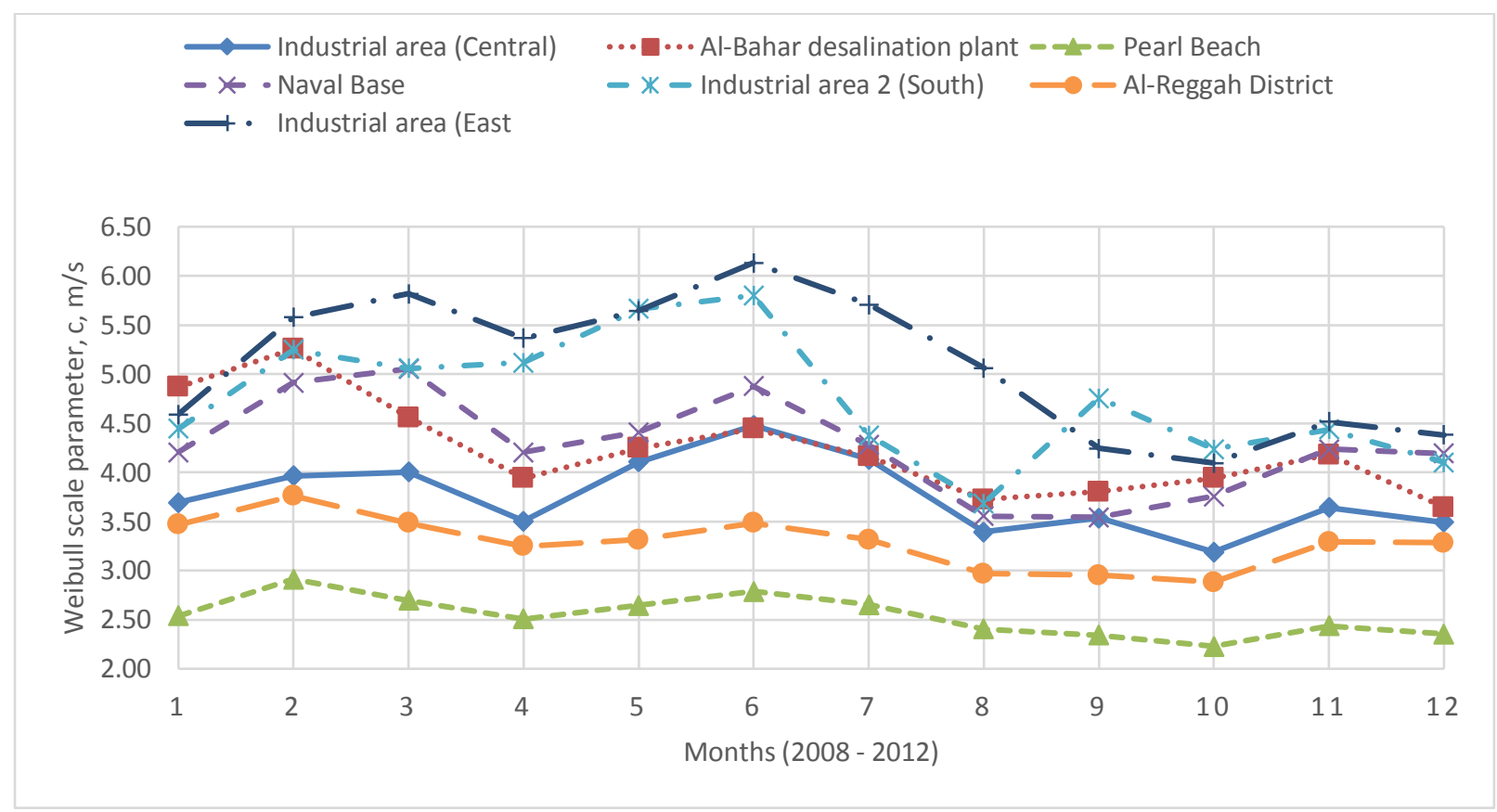

Fig. 9. Monthly variation of Weibull scale parameter, $c, \mathrm{~m} / \mathrm{s}$ at all sites. 


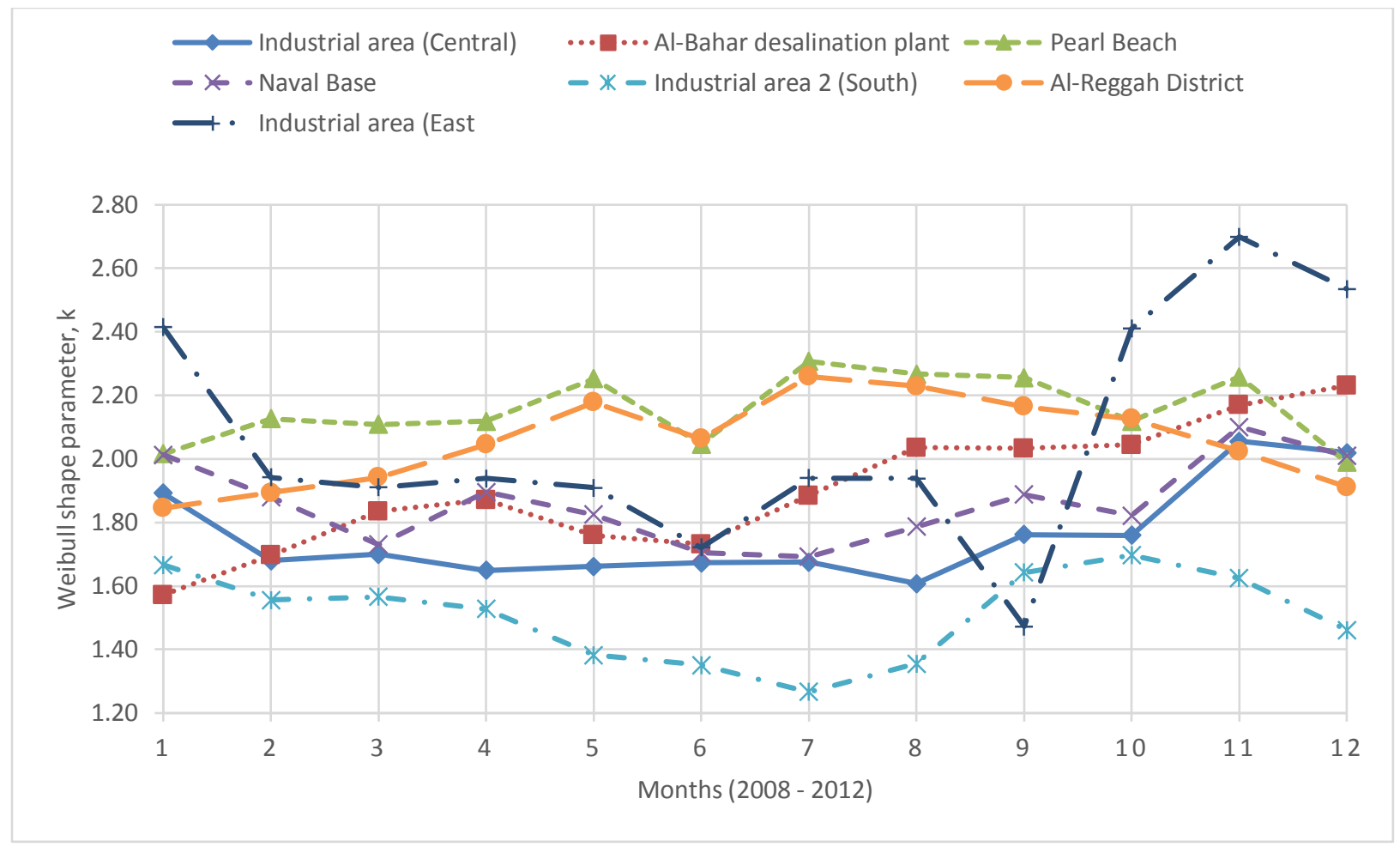

Fig. 10. Monthly variation of Weibull shape parameter, $k$ at all sites.

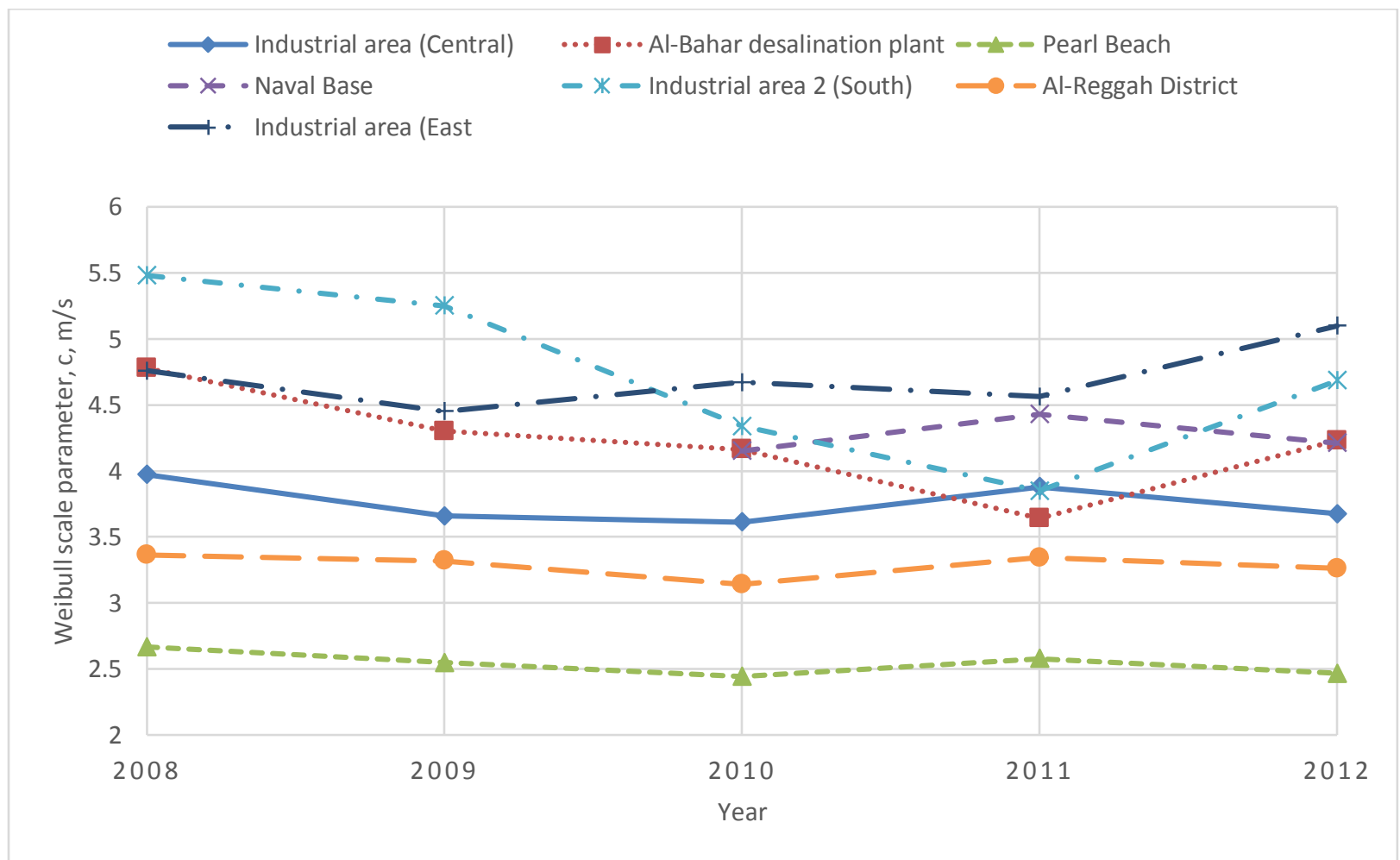

Fig. 11. Annual variation of Weibull scale parameter, $c, \mathrm{~m} / \mathrm{s}$ at all sites. 


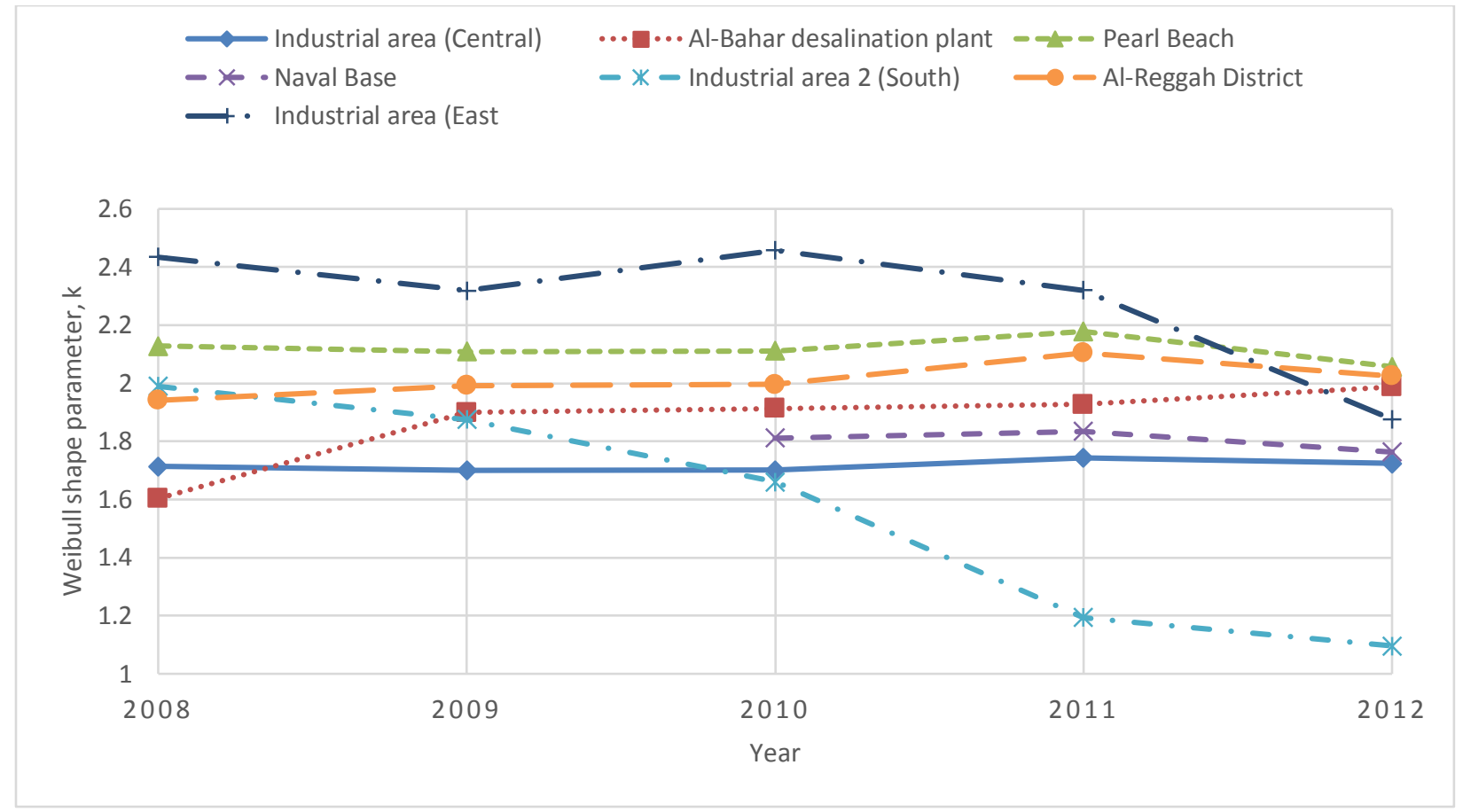

Fig. 12. Annual variation of Weibull shape parameter, $k$ at all sites.

\subsection{Most Probable Wind Speed}

The most probable wind speed simply provides the most frequently occurring wind speed for a given wind probability distribution. In high wind potential sites, the most probable wind speed is close to the rated wind speed for a given wind machine. The most probable wind speed can be calculated using the Weibull shape and scale parameters via the following equation [22]:

$$
V_{m p}=c\left(1-\frac{1}{k}\right)^{\frac{1}{k}}
$$

The most probable wind speed at all the seven locations at $10 \mathrm{~m}$ AGL was found using all three estimation methods and is shown in Fig. 13. All three estimation methods showed similar results. The highest most probable wind speeds determined by maximum likelihood method, least-square regression methods and WAsP are 3.39, 3.6 and $3.24 \mathrm{~m} / \mathrm{s}$ respectively and were observed at Industrial area (east). 


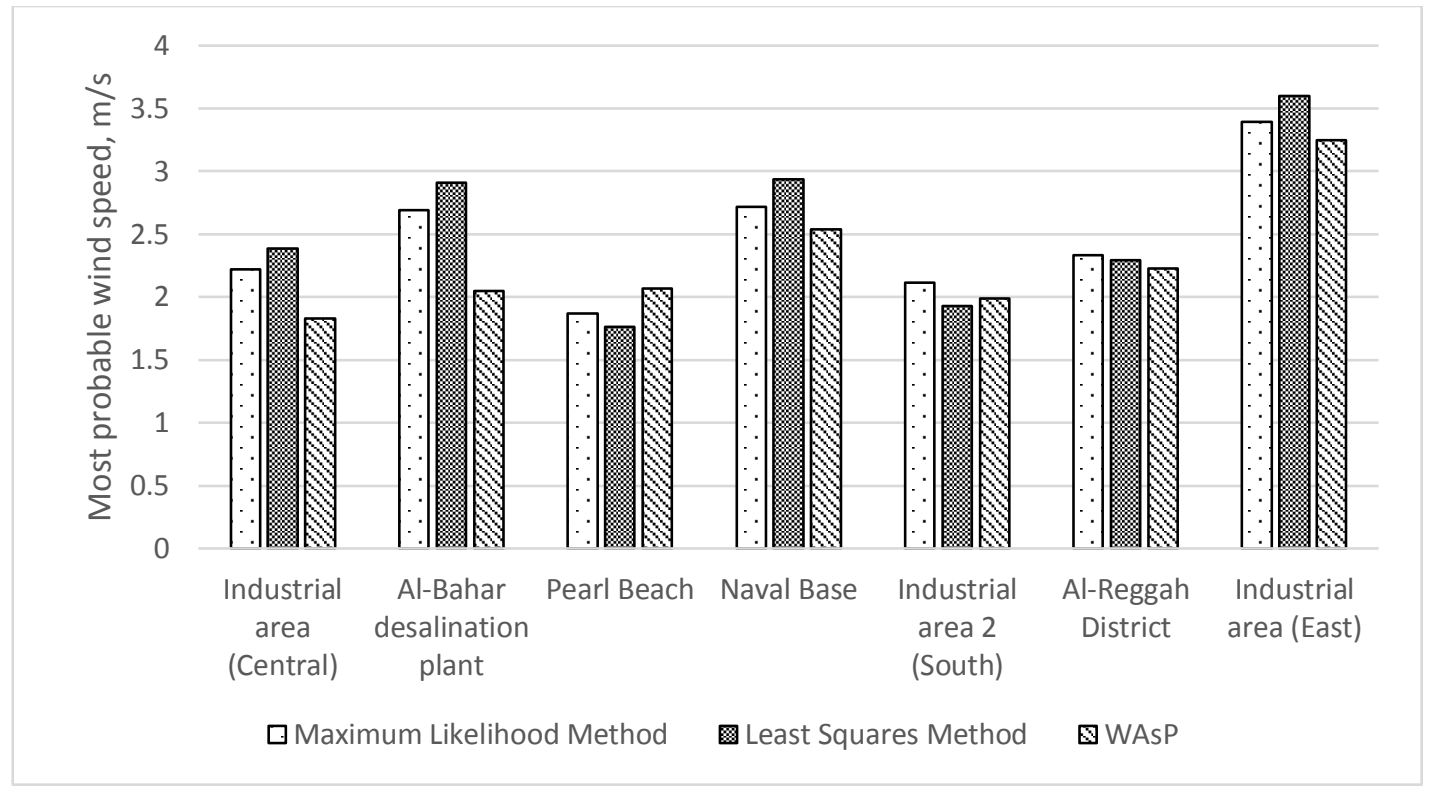

Fig. 13. Most probable wind speed at all sites.

\subsection{Maximum Energy Carrying Wind Speed Estimation}

The maximum energy carrying wind speed is the speed which generates maximum energy. This can be estimated from the Weibull parameters through the following relationship [22]:

$$
V_{\max , E}=c\left(1+\frac{2}{k}\right)^{\frac{1}{k}}
$$

The maximum energy carrying wind speed at all the seven locations at $10 \mathrm{~m}$ AGL was found using all three estimation methods is shown in Fig. 14 below. All three estimation methods showed similar results. The highest maximum energy carrying wind speed values of $8.61,9.0$ and $8.68 \mathrm{~m} / \mathrm{s}$; determined by maximum likelihood method, leastsquare regression methods and WAsP; were observed at Industrial area 2 (south). While at Industrial area (east) the respective values were found to be $7.5,7.2$ and $7.7 \mathrm{~m} / \mathrm{s}$ respectively. These wind speeds are indicative of producing maximum energy in industrial area 2 (south) and industrial area (east). 


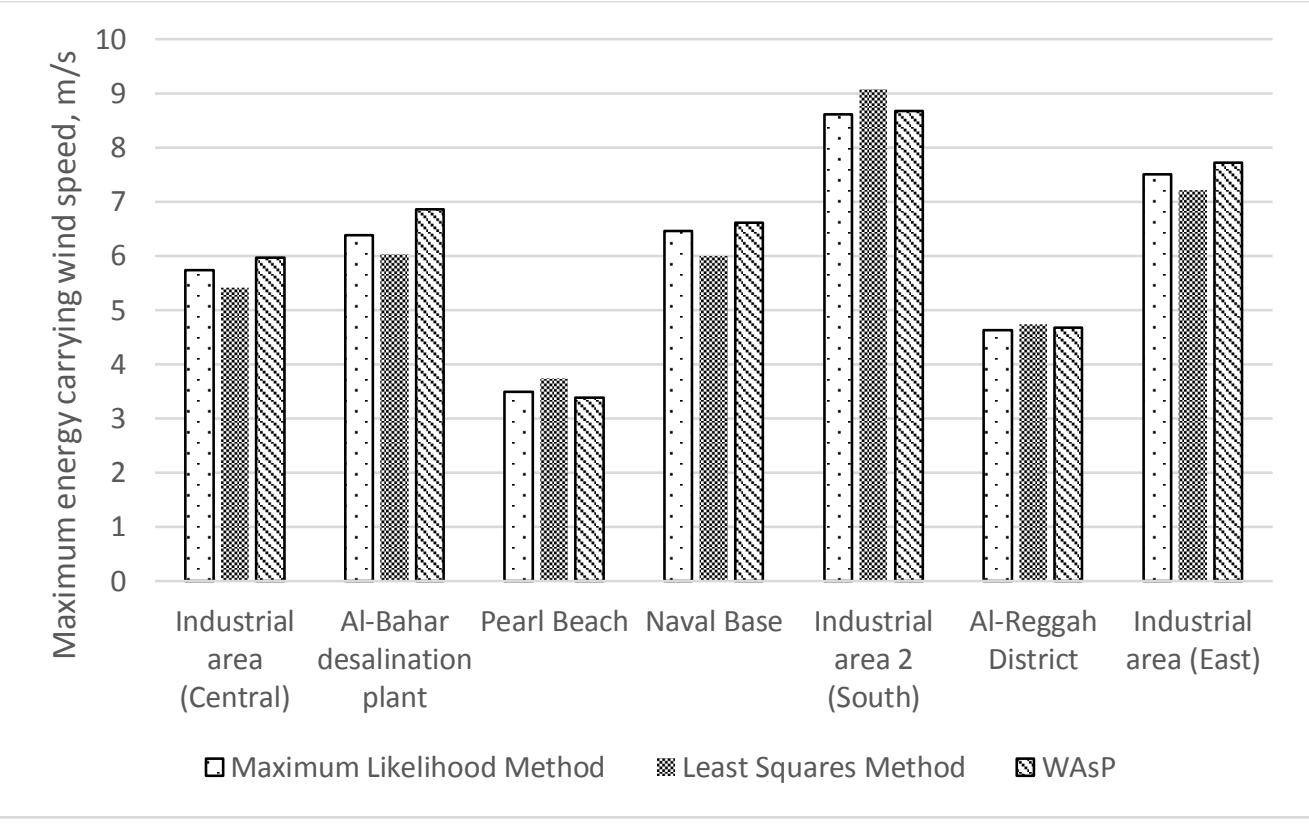

Fig. 14. Maximum energy carrying wind speed at all sites.

\subsection{Energy Output}

The wind energy output from five different commercially available wind machines with rated power of 1.8 to $3.3 \mathrm{MW}$ was determined at all the sites. The wind speed frequency at different hub heights at all sites was determined by vertical extrapolation of wind speed using the local wind shear exponent value of 0.217 . This value of wind shear coefficient was obtained by using measured wind speed at 10,50 and $90 \mathrm{~m}$ heights AGL at Industrial area (central).

The wind shear coefficient, $\alpha$, was calculated using the following equation [23]:

$$
\alpha=\frac{\ln \left(V_{2}\right)-\ln \left(V_{1}\right)}{\ln \left(Z_{2}\right)-\ln \left(Z_{1}\right)}
$$

Where $V_{1}$ and $V_{2}$ are wind speeds at height $Z_{1}$ and $Z_{2}$ respectively.

The air density used in energy output calculations, was calculated using the local pressure and temperature measurements at Industrial area (central).

The air density, $\rho$ was calculated using the following equation: 


$$
P=\frac{\rho}{R T} \quad\left(\mathrm{Kg} / \mathrm{m}^{3}\right)
$$

Where $P$ is the air pressure in Pascals, $R$ is the specific gas constant of air, $287.05 \mathrm{~J} / \mathrm{kg} . \mathrm{K}$ and $T$ is the local air temperature in degrees Kelvin. An overall mean air density at this station was found to be $1.17 \mathrm{~kg} / \mathrm{m}^{3}$. To find the energy output from selected wind turbine, the number of hours the wind speed remained in different wind speed bins is determined at the turbine hub height. Then using the power curve data of the selected wind machine, the energy output is calculated. In this study, the energy output is calculated using Windographer [20] software. The plant capacity factor, PCF is the ratio of its actual annual output, to its rated output. The technical specifications of wind machines used in this study are summarised in Table 15. The annual energy output in MWh/year and Plant capacity factor, PCF in \% is presented in Figure 15 and 16 respectively. It can be observed from these figures that the most feasible site for wind farm development in Jubail city is Industrial area (East). At this site, the maximum energy output of 11,135 MWh/year was obtained at a PCF of $41.3 \%$ from a commercially available wind machine of $3 \mathrm{MW}$ rated power.

The comparison of \% PCF of these five wind machines at all sites reveals that wind machine 5 (1.8 MW rated power) is most efficient at all sites in Jubail. A low rated power wind machine is more efficient for low or mediocre wind potential areas [23]. Wind machines 1, 2 and 4 of rated power 3.3, 3.0 and 2.0 MW respectively were found to have similar mediocre efficiency. Wind machine 3 (2.6 rated power) is found to be least efficient for all sites Jubail.

Table 15 Technical data of wind machines [19]

\begin{tabular}{|c|c|c|c|c|c|c|}
\hline $\begin{array}{c}\text { Wind } \\
\text { machine }\end{array}$ & $\begin{array}{c}\text { Cut-in } \\
\text { speed } \\
(\mathrm{m} / \mathrm{s})\end{array}$ & $\begin{array}{c}\text { Cut-out } \\
\text { speed } \\
(\mathrm{m} / \mathrm{s})\end{array}$ & $\begin{array}{c}\text { Rated } \\
\text { output } \\
(\mathrm{kW})\end{array}$ & $\begin{array}{c}\text { Rated wind } \\
\text { speed }(\mathrm{m} / \mathrm{s})\end{array}$ & $\begin{array}{c}\text { Hub } \\
\text { height } \\
(\mathrm{m})\end{array}$ & $\begin{array}{c}\text { Rotor } \\
\text { diameter } \\
(\mathrm{m})\end{array}$ \\
\hline WM 1 & 3 & 25 & 3300 & 12 & 117 & 126 \\
\hline WM 2 & 3 & 22.5 & 3000 & 12 & 119 & 126 \\
\hline WM 3 & 4 & 23 & 2600 & 15 & 75 & 100 \\
\hline WM 4 & 3 & 25 & 2000 & 11.5 & 80 & 110 \\
\hline WM 5 & 4 & 20 & 1800 & 12 & 80 & 100 \\
\hline
\end{tabular}




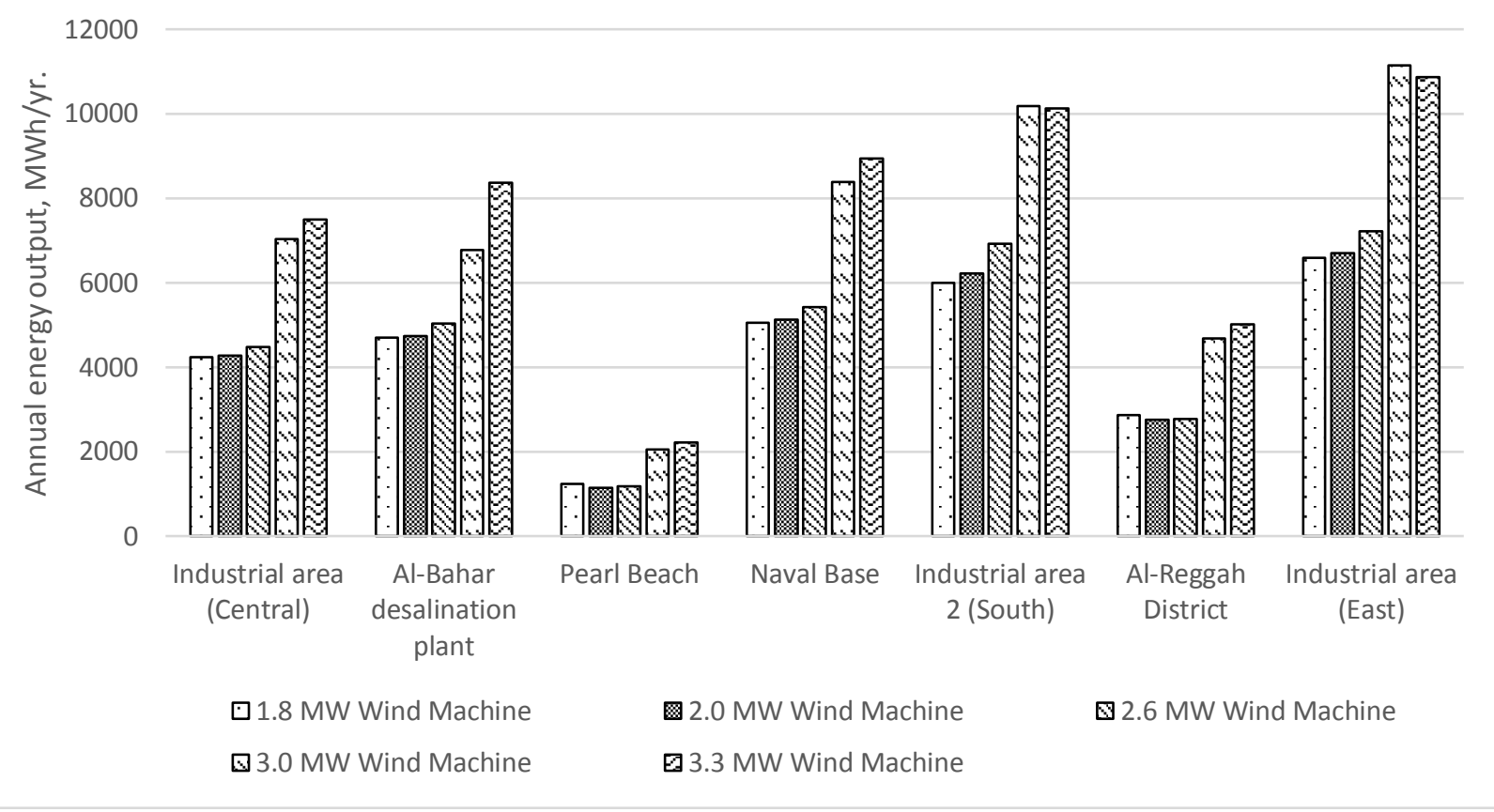

Fig. 15. Annual energy output of different wind machines at all sites.

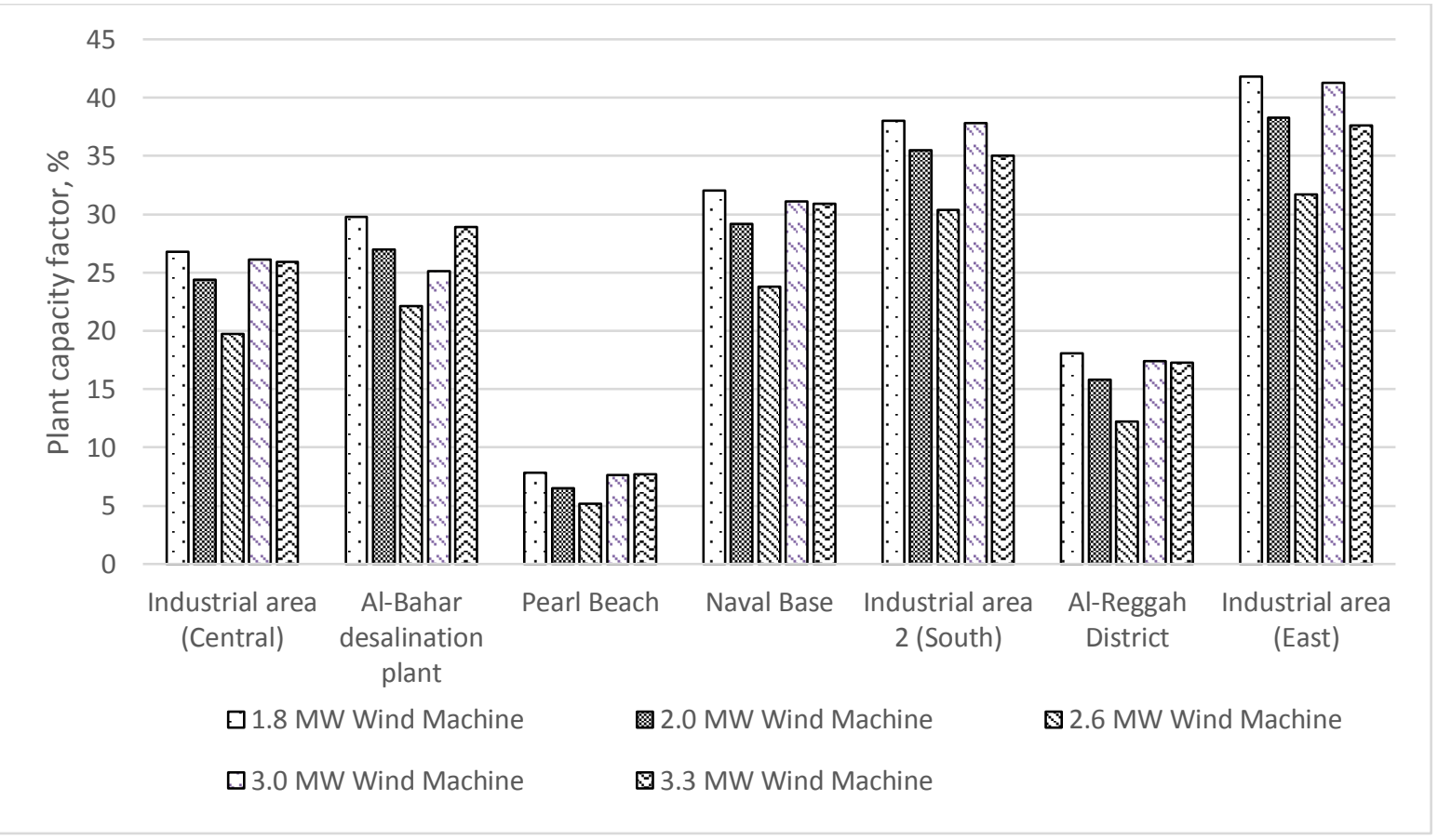

Fig. 16. Plant capacity factor of different wind machines at all sites. 


\section{Concluding Remarks}

The following main observations can be drawn from this study:

The wind characteristics of seven locations in Jubail, Saudi Arabia were analysed. At 10 m AGL, the annual mean wind speeds varied from $2.25 \mathrm{~m} / \mathrm{s}$ (standard deviation 1.109 $\mathrm{m} / \mathrm{s}$ ) at Pearl beach to $4.52 \mathrm{~m} / \mathrm{s}$ (standard deviation $2.52 \mathrm{~m} / \mathrm{s}$ ) at Industrial area (east). In general, at all sites, the highest monthly mean wind speed was observed in February/June and the lowest in September/October. The period of higher winds availability coincides with high power demand period of the area due to air conditioning load. The most prevailing wind direction was from the north-west which means that the wind machines can spread facing the prevailing wind direction.

The goodness-of-fit test indicators, i.e., $R^{2}, R S M E, M B E$ and $M A E$ show that the maximum likelihood method is the most efficient method of Weibull parameter estimation for Jubail region followed by least square regression method and WAsP. The highest value of most probable wind speed was found to be in the range $3.2 \mathrm{~m} / \mathrm{s}$ to 3.6 $\mathrm{m} / \mathrm{s}$ at industrial area (east) by three estimation methods. The highest value of maximum energy carrying wind speed was found to be in the range $8.6 \mathrm{~m} / \mathrm{s}$ to $9.0 \mathrm{~m} / \mathrm{s}$ at industrial area 2 (south) by three estimation methods.

The wind energy output from five different commercially available wind machines with rated output ranging from 1.8 to $3.3 \mathrm{MW}$ at all the sites shows that most feasible site for wind farm development in Jubail city is Industrial area (East). At this site, the maximum energy output of 11,135 MWh/year with a PCF of $41.3 \%$ from a $3 \mathrm{MW}$ rated power wind machine was obtained. The second best site for wind farm development is Industrial area 2 (south). At this site, the maximum energy output of 10,180 MWh/year with a PCF of $37.8 \%$ from a $3 \mathrm{MW}$ rated power wind machine was obtained. From \% PCF, it can be concluded that Wind machine 5 (1.8 MW rated power) is most efficient at all sites in Jubail as a low rated power wind machine is more efficient for mediocre wind potential areas. 


\section{Acknowledgement:}

The authors would like to acknowledge Jubail industrial college, Royal commission for Jubail and Yanbo, Saudi Arabia for providing the weather data used in this study. The authors would also like to acknowledge the technical support and guidance provided by King Fahd University of Petroleum and Minerals, Dhahran-31261, Saudi Arabia and University of Pretoria, Pretoria, Republic of South Africa.

\section{References}

[1] Rehman, S., Halawani, T. O., and Husain, T. (1994). Weibull Parameters for Wind Speed Distribution in Saudi Arabia. Solar Energy 53(6): 473-479

[2] Wentink, T. 1976. Study of Alaskan wind power potential and its possible applications. Final Report (Rep. No. NSF/RANN/SE/AER 74-00239/FR-76/ 1), Geophysical Institute, University of Alaska.

[3] Rehman, S. and Halawani, T. O. (1994). Statistical characteristics of wind in Saudi Arabia. Renewable Energy 4(8): 949-956.

[4] Islam, M.R., R. Saidur, and N.A. Rahim. (2011). Assessment of wind energy potentiality at Kudat and Labuan, Malaysia using Weibull distribution function. Energy 36(2):985-92.

[5] Rehman, S., A. M. Mahbub Alam, J. P. Meyer, L. M. Al-Hadhrami. (2012). Wind speed characteristics and resource assessment using Weibull parameters. International Journal of Green Energy 9: 800-814.

[6] Stevens, M.J.M., and Smulders, P.T. (1979). The estimation of the parameters of the Weibull wind speed distribution for wind energy utilization purposes. Wind Engineering 3(2): 132-45.

[7] Seguro, J.V., Lambert, T.W. (2000). Modern estimation of the parameters of the Weibull wind speed distribution for wind energy analysis. Journal of Wind Engineering and Industrial Aerodynamics 85: 75-84. 
[8] Bagiorgas, H.S., Giouli, M., Rehman, S., Al-Hadhrami, L.M. (2011). Weibull parameters estimation using four different methods and most energy-carrying wind speed analysis. International Journal of Green Energy 8 (5): 529-554.

[9] Costa Rocha, P.A., de Sousa, R.C., de Andrade, C.F., and da Silva, M.E.V. (2012). Comparison of seven numerical methods for determining Weibull parameters for wind energy generation in the northeast region of Brazil. Appl. Energy 89: 395-400.

[10] Seyit A. Akdag, and Ali Dinler. (2009). A new method to estimate Weibull parameters for wind energy applications. Energy Conversion and Management 50: 1761-1766.

[11] Philippopoulos K, Deligiorgi D, and Karvounis G. (2012). Wind speed distribution modeling in the greater area of Chania, Greece. International Journal of Green Energy 9: 174-193.

[12] Faruk Kose, Muharrem Hilmi Aksoy, and Muammer Ozgoren. (2014). An Assessment of Wind Energy Potential to Meet Electricity Demand and Economic Feasibility in Konya, Turkey. International Journal of Green Energy 11 (6): 559-576

[13] Florin Onea, and Eugen Rusu. (2014). An evaluation of the wind energy in the north-west of the black sea. International Journal of Green Energy 11(5): 465-487.

[14] The Vision, King Abdullah City of Atomic and Renewable energy (KACARE). Available at: $\quad$ http://www.kacare.gov.sa/en/?page_id=84> (Accessed 30.03.2016)

[15] Kalogirou, Soteris A. Michaelides, Silas. (2004) Time series prediction of wind speed Proceedings of the 7th Panhellenic (International) Conference of Meteorology, Climatology and Atmospheric Physics, Nicosia, Cyprus, Vol. 1, pp. 294-299

[16] The Saline Water Conversion Corporation (SWCC) Available at: <http://www.swcc.gov.sa/english/pages/home.aspx> (Accessed 4.4.2016) 
[17] Kalogirou, S. (2005). Seawater Desalination Using Renewable Energy Sources. Progress in Energy and Combustion Science 31 (3): 242-281.

[18] F.C. Odo, S.U. Offiah and P.E. Ugwuoke. (2012). Weibull distribution-based model for prediction of wind potential in Enugu, Nigeria. Advances in Applied Science Research 3 (2): 1202-1208.

[19] Justus, C.G., Hargraves, W.R., Mikhail, A., and Graber, D. (1978). Methods for estimating wind speed frequency distributions. Journal of Applied Meteorology 17:350-353.

[20] Windographer 3.2.3, 2014. Wind Resources Assessment Tool. http://www.mitsaya.com.

[21] De Miguel, A., Bilbao, J. (2005). Test reference year generation from meteorological and simulated solar radiation data. Solar Energy, 78, Issue 6, 695822.

[22] Akpinar, E. K., and Akpinar, S. (2005). An assessment on seasonal analysis of wind energy characteristics and wind turbine characteristics. Energy Conversion and Management 46(11-12): 1848-1867.

[23] Alawaji S.H., Eugenio N.N., Elani U.A. (1996). Wind energy resource assessment in Saudi Arabia. Part II: Data Collection and Analysis. Renewable Energy 9 (4): 818-821.

[24] Panayiotou, G., Kalogirou, S., Tassou, S. (2012). Design and Simulation of a PV and a PV-Wind Standalone Energy System to power a Household Application, Renewable Energy 37 (1): 355-363. 